\title{
The Effort To Reduce Negative Externality In Post Covid-19 Period In Turkish Economy: Example Of Transportation Sector
}

\author{
Türkiye Ekonomisinde Covid-19 Sonrası Negatif Dışsallı̆̆ı Azaltma Çabası: Ulaştırma Sektörü Örneği \\ İlkay GÜLER ${ }^{\mathrm{a} *}$ \\ ${ }^{a}$ Öğr.Gör.Dr., Ankara Hacı Bayram Veli Üniversitesi, Tapu Kadastro Yüksekokulu, Emlak ve Emlak Yönetimi Bölümü, Ankara/ TÜRKIYE \\ ORCID: 0000-0003-1289-6652
}

\begin{tabular}{l} 
M A K A L E B İ L G İ S İ \\
\hline Makale Geçmişi: \\
Başvuru tarihi: 20 Haziran2020 \\
Kabul tarihi: 25 Ekim 2020 \\
\hline Anahtar Kelimeler: \\
Ekolojik Ekonomi, \\
Negatif Dışsallık, \\
Çevresel Olarak Genişletilmiş Girdi-Çıktı \\
Analizi, \\
Covid-19, \\
Ulaştırma Sektörü
\end{tabular}

\section{A R T I C LE INFO}

Article History:

Received June 20, 2020

Accepted October 25, 2020

\section{Keywords:}

Ecological Economy,

Negative Externality,

Environmentally Extended Input-Output

Analysis,

Covid-19,

Transport Sector

\section{Ö Z}

Her üretim unsuru beraberinde negatif dışsallık yaratmaktadır. Bu çalışmada, ulaştırma sektörünün yarattığı negatif dișsallık genişletilmiş çevresel girdi-çıktı analizi ile incelenmektedir. WIOD girdi-çıktı tablosunda ulaştırma sektörü kara taşımacılığı, hava taşımacılığı, su taşımacılığı olmak üzere üç sektör olarak yer almaktadır. Bu bağlamda gerçekleştirilen analiz sonucunda, normalized total backward CO2 linkages coefficients sırasıyla; kara tașımacılığında, 0,4500 kt CO2 eșdeğeri, hava taşımacılığında, 0,8929 kt CO2 eşdeğeri, su taşmacılığı, 0,3619 kt CO2 eşdeğeridir. Normalized total forward CO2 linkages coefficients ise; kara taşımacılığında $1,1895 \mathrm{kt} \mathrm{CO} 2$ eşdeğeri, hava taşımacılığında, $0,7840 \mathrm{kt} \mathrm{CO} 2$ eşdeğeri ve su taşımacılığında, 0,3234 kt CO2 eşdeğeri olarak bulunmuştur. Ulaştırma sektörlerinin, dönemler arası üretim zincirinin yapısal olarak değişip değişmediğinin belirlenmesi için Spearman korelasyonu katsayısı hesaplanmıștır. Üretimde kullanılan girdi bileşenlerinin anlamlı bir şekilde farklılaşmadığı sonucuna ulaşılmıştır. Elde edilen sonuçların Covid-19 sonrası süreçte daha da artacağı öngülmekte, ivedilikle; emisyon üretimini sınırlandırmaya yönelik politikaların uygulandığı, yenilenebilir ve sürdürülebilir çevre dostu yakıt türlerinin tercih edildiği bir ulaştırma sisteminin oluşturulması yönünde politikalar belirlenerek önemler alınması önerilmektedir.

\section{A B S T R A C T}

Every production element creates negative externality. In this study, the negative externality created by the transportation sector is investigated by extended environmental input-output analysis. In the WIOD inputoutput table, the transportation sector consists of three sectors as land transportation, air transportation and water transportation. As a result of the analysis carried out in this context, normalized total backward $\mathrm{CO} 2$ linkages coefficients are $0,4500 \mathrm{kt} \mathrm{CO} 2$ equivalent in land transportation, 0,8929 kt CO2 equivalent in air transportation, and $0,3619 \mathrm{kt} \mathrm{CO} 2$ equivalent in water transportation respectively. Normalized total forward $\mathrm{CO} 2$ linkages coefficients were found as $1,1895 \mathrm{kt} \mathrm{CO} 2$ equivalent in land transportation, $0.77840 \mathrm{kt} \mathrm{CO} 2$ equivalent in air transportation and $0.3234 \mathrm{kt} \mathrm{CO} 2$ equivalent in water transportation. The Spearman correlation coefficient was calculated to determine whether the transportation sectors' inter-period production chain changed structurally. It was concluded that the input components used in production did not differ significantly. It is predicted that the obtained results will increase even more in the post-Covid-19 period and it is recommended to take measures and determine policies for a transportation system in which emission production is limited and renewable and sustainable environmentally friendly fuel types are preferred.

\footnotetext{
* Sorumlu yazar/Corresponding author.

e-posta: ilkay.guler@hbv.edu.tr
} 


\section{EXTENDED ABSTRACT}

Girdi-çıktı analizinin, iktisadi çalışma alanı temel olarak sektörlerdir. Günümüzde tüm sektörler birbiri ile bağlantılıdır. Sektörler, uyguladıkları üretim teknikleri ile girdileri çıktı şekline getiren üretim unsurlarıdır. Ancak her üretim unsuru beraberinde çevresel negatif dışsallık yaratmaktadır. Bu çalışmada, çevresel negatif dışsallık olarak CO2 emisyonu ele alınarak Türkiye'deki tüm sektörlere genişletilmiş çevresel girdi-çıktı analizi uygulanmış, ulaştırma sektörü özelinde değerlendirilip, önlemler, politikalar ve öneriler sunulmuștur.

WIOD girdi-çıktı tablosunda ulaştırma sektörü kara taşımacılığı, hava taşımacılığı, su taşımacılığı olmak üzere üç sektör olarak yer almaktadır. Kara taşımacılığının bir dolarlık üretimin 0,1356 kt CO2 eşdeğeri, kara taşımacılığı sektörünün 1 dolarlık nihai talep artışı sonucu tüm sektörlerde yarattığı üretim artışının 0,4500 kt CO2 eşdeğeri, tüm sektörlerin 1 dolarlık nihai talep artış1 sonucu tüm sektörlerde yarattığ üretim artışının CO2 emisyonu ise 1,1895 kt CO2 eşdeğeri'dir. Kara taşımacılığ1 sektörünün kısmi geri bağlantı katsayısı incelendiğinde kendi sektöründen sonra elektrik, gaz, buhar ve iklimlendirme temini sektörü ile kok kömürü ve rafine edilmiş petrol ürünleri imalatı sektörü en fazla emisyon üretim katsayısına sahip sektörlerdir. Sektörün kısmi ileri bağlantı katsayısı incelendiğinde kendi sektöründen sonra depolama ve destekleyici faaliyetler sektörü, kok kömürü ve rafine edilmiş petrol ürünleri imalatı sektörleri yer almaktadır. Türkiye'de emisyon üretiminin fazlalığının yanında gürültü kirliliği, görüntü kirliliği ve trafik sıkışıklığına da neden olan kara taşımacılığına yönelik emisyon azaltıcı önlemler alınmalıdır.

Hava taşımacılığı sektörü açısından bakıldığında, bir dolarlık üretimin 0,3437 kt CO2 eşdeğeri, hava taşımacılığı sektörünün 1 dolarlık nihai talep artışı sonucu tüm sektörlerde yarattığ sonucu tüm sektörlerde yarattığı üretim artışı sonucu CO2 emisyonu ise 0,7840 kt CO2 eşdeğeridir. Hava taşımacılığı sektörünün kısmi geri bağlantı katsayısı incelendiğinde kendi sektöründen sonra elektrik, gaz, buhar ve iklimlendirme temini sektörü ile kok kömürü ve rafine edilmiş petrol ürünleri imalatı sektörleri en fazla emisyon üretim katsayısına sahip sektörlerdir. Sektörün kısmi ileri bağlantı katsayısı incelendiğinde kendi sektöründen sonra kamu yönetimi ve savunma; zorunlu sosyal güvenlik sektörü ile telekomünikasyon sektörleri yer almaktadır. Bu bağlamda Endüstri 4.0'ın etkisindeki sektörlerin, savunma ve iletişim alanındaki üretim faaliyetlerine yönelik emisyon değerlerini düşürmeyi amaçlayan önlemler alması gerekmektedir.

Su taşımacılığı sektörü açısından bir dolarlık üretim sonucu 0,1068 kt CO2 eşdeğeri, su taşımacılığı sektörünün 1 dolarlık nihai talep artışı sonucu tüm sektörlerde yarattığı üretim artışının CO2 emisyonu 0,3619 kt CO2 eşdeğeri, tüm sektörlerin 1 dolarlık nihai talep artış1 sonucu tüm sektörlerde yarattığ1 üretim artışı sonucu meydana gelen CO2 emisyonu 0,3234 kt CO2 eşdeğeridir. Su taşımacılığ1 sektörünün kısmi geri bağlantı katsayısı incelendiğinde kendi sektöründen sonra ilk sırada elektrik, gaz, buhar ve iklimlendirme temini sektörü ikinci sırada, kok kömürü ve rafine edilmiş petrol ürünleri imalatı sektörleri en fazla emisyon üretim katsayısına sahip sektörlerdir. Sektörün kısmi ileri bağlantı katsayısı incelendiğinde kendi sektöründen sonra en büyük katsayı, perakende ticaret ile kok kömürü ve rafine edilmiş petrol sektörleri yer almaktadır. Türkiye'de su taşımacıllı̆̆ genellikle yük taşımacılığı odaklı lojistik amaçlı kullanıma göre şekillenmektedir. Ayrıca kömür ve petrol ürünlerinin taşımacılığı da karayolu ve demiryolu taşımacılığının yanında su taşımacılığıyla da sağlanmaktadır. Bu daha az emisyon üreten sektör olan su taşımacılığının üç tarafı denizlerle çevrili ülkemizde daha az kullanılıyor olması yük ve yolcu taşımacılığı açısından su taşımacılığına daha çok öncelik veren önlemlerin alınmasını gerekli k1lmaktadır.

Günümüzde hava kirliliğinin azaltılması pek çok ülke tarafından hedeflenmektedir. Üretimin durması, enerji tüketiminin azalması, ulaştırma araçlarının kullanılmaması, yeme-içme, alışveriş, eğlence faaliyetlerinin durdurulması vb. gibi nedenler söz konusu olduğunda hava kirliliğinin azalması beklenen bir durumdur. Örneğin; bugünlerde Çin'den başlayarak tüm dünyaya yayılan, arz şokunu tetikleyen Covid-19 pandemisi nedeniyle, halkın evlerinde kendi karantinalarını uygulaması, ev dışında geçirilen faaliyetlerin, ulaştırma faaliyetlerinin kısıtlanması ve pek çok fabrikanın üretimi durdurması nedeniyle hava kirliliğinde azalma gözlemlenmiş. NASA tarafından yayımlanan uydu görüntülerinde hem 1-20 Ocak 2020 ve 10-25 Şubat 2020 karşılaştırıldığında hem de aynı tarihlerin geçen yılki uydu görüntüleri karşılaştırıldığında hava kirliliğindeki azalma net bir şekilde görülmektedir (NASA, 2020), Bir taraftan ticaret savaşından kurtulmak, diğer taraftan COVID-19 virüsü ile mücadele etmek sonucu mali şok ve durgunluk beklentisi söz konusudur(WORLD BANK, 2020, pp. 2-3). Önemli olan ekonomik durgunluğun olmadığı, üretimin devam ettiği, üretilen ürünlerin insanlara ulaştırıldığı, insanların ulaştırma araçlarını aktif bir şekilde kullandığı dönemlerde hava kirliliğinin azaltılmasıdır. Bu bağlamda son on yılda, hava-kara-demiryolu-su taşımacılığı alanında Türkiye'nin, sürdürülebilirlik, çevreye duyarlılık, insan odaklılık, enerji verimlilik, yaşanabilirlik temeline odaklanan eylem planı, strateji ve politika belgeleri ile bu çalışmada gerçekleştirilen analiz sonuçları bir arada değerlendirildiğinde; Mevcut ulaşım altyapısının enerji ve maliyet etkin planlandığı, insan odaklı olduğu, çevre dostu taşıt türlerinin yaygınlaştırıldığı, motorsuz ulaşım türlerinin tercih edildiği, emisyon üreten farklı ulaşım sektörleri arasında taşımacılığın yoğunlaştırıldığı, hava taşımacılığında daha az yakıt sarfiyatının sağlandığı, kentsel toplu ulaşımda türler arası entegrasyonun sağlandığı ayrıca alternatif ulaşım sistemlerinin tercih edildiği, , yakıt sarfiyatının azaltıldığ 1 ve fosil yakıt kullanımının kısıtlandığı, kentin emisyon yoğunluğunu ve emisyon üretimini sınırlandırmaya yönelik politikaların uygulandığı, yenilenebilir ve sürdürülebilir çevre dostu yakıt türlerinin tercih edildiği bir ulaştırma sisteminin oluşturulması yönünde politikalar belirlenerek önemler alınması tarafımızca önerilmektedir.

WIOD veri tabanında yayımlanan girdi-çıktı tablolarında çevre dostu yakıt türleri üretimi ve kullanımı ile çevreye duyarlı elektrikli, hibrit, güneş, hidrojen, rüzgâr enerjili taşıt türleri gibi çevreye zarar vermeyen taşıtların üretimi ve kullanımı sektör olarak yer almamaktadır. Bundan sonra oluşturulacak girdi-çıktı tablolarında söz konusu sektörlerin yer alması tarafımızca önerilmektedir. Böyle bir durumda sektörlerin CO2 emisyonunu azaltmak için, girdi çıktı tablosunda kömür ve petrol türevleri katsayılarının yüzdesel olarak azaltılıp, çevre dostu yakıt türleri katsayılarının yüzdesel olarak arttırıldığı; hâlihazırda kullanılan taşıtların kullanım katsayılarının yüzdesel olarak azaltılıp, çevreye duyarlı araçların katsayılarının yüzdesel olarak arttırıldığı çeşitli senaryolar hazırlanarak, genişletilmiş çevresel girdi-çıktı analizleri gerçekleştirilebilir. Dolayısıyla bu çalışma kapsamında ortaya koyduğumuz önlem ve politikaların geçerliliğinin kanıtlanacă̆ı tarafımızca ön görülmektedir. 


\section{Introduction}

Transport sector is among the primary sectors about the final energy consumption in many countries. When compared to other sectors, it plays a significant role in economy ranking the second in the global level $\mathrm{CO}_{2}$ emission production. In this regard, it is inevitable that it is far more effective than all the economic sectors affecting the climate change (Chung, Yeung and Zhou, 2013; Soleymani, 2019, p. 990; Van Dender, 2009).

According to the statistics of International Energy Agency, (IEA, 2020), when sectoral distribution of $\mathrm{CO}_{2}$ emission production between 1990 and 2018 is analyzed, it is observed that transport sector ranks the second with 83 million tones $\mathrm{CO}_{2}$ in the year 2017 (Figure 1). According to the Fourth Biennial Report of Turkey published in the United Nations Framework Convention on Climate Change (UNFCCC, 2019), while the total amount of greenhouse gas emission was $36.464,87 \mathrm{kt} \mathrm{CO}_{2}$ equivalent in the year 2000, this amount rose to $45.391,99 \mathrm{kt}$ $\mathrm{CO}_{2}$ equivalent in 2010. It has been estimated that $\mathrm{CO}_{2}$ equivalent will be $101.189,82 \mathrm{kt}$ for the year 2020. According to this report, the total amount of greenhouse gas emission produced in the Turkish transport sector, $\mathrm{CO}_{2}$ equivalent is predicted to be $136.512,60 \mathrm{kt} \mathrm{CO}_{2}$ equivalent for the year 2030.This change is the proof that especially the transport sector takes place among the primary sectors in environment polluting emission production that causes climate change.

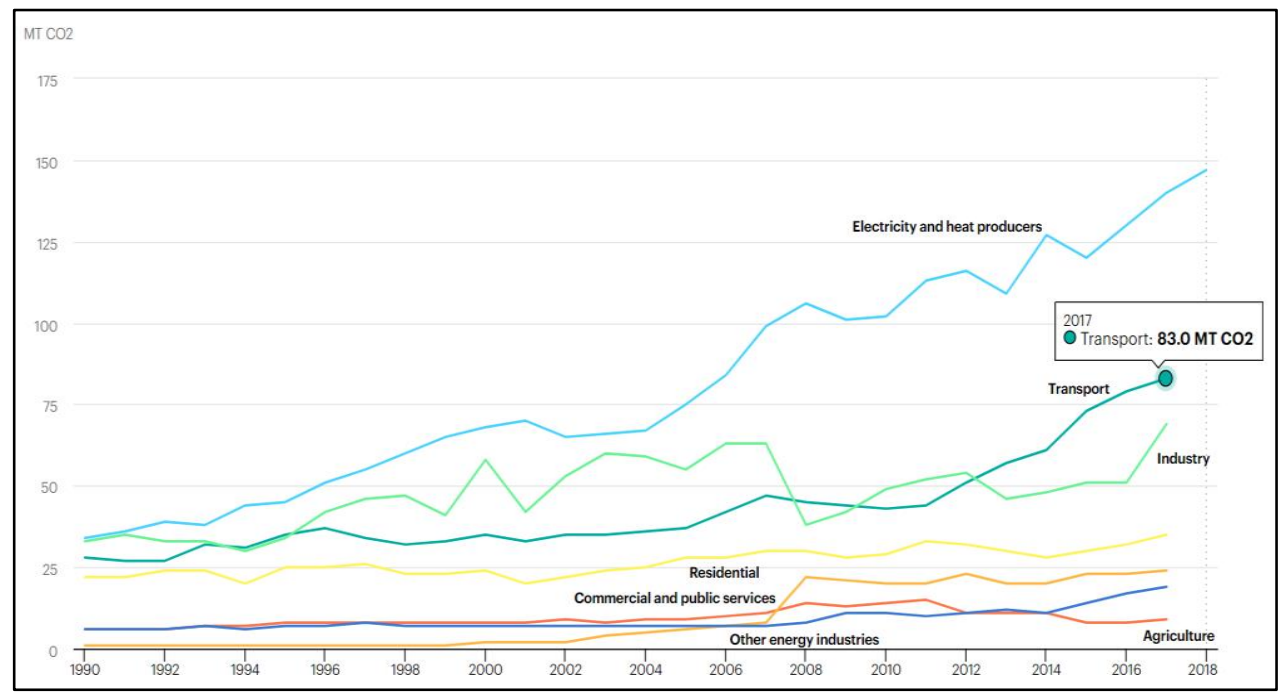

Figure 1: Sectoral Distribution of CO2 Production Between the Years 1990-2018 in Turkey Resource: IEA, 2020.

$\mathrm{CO}_{2}$ emissions consist of the sum total of the processes arising in consequence of the industrial production (irrelated with the energy industry $=\mathrm{CO}_{2}$ nen) and energy (energy $=\mathrm{CO}_{2}$ en) derived from the fuel consumption and expressed via the formulation of $\mathrm{CO}_{2(\mathrm{c}, \mathrm{s}, \mathrm{t})}=$ $\mathrm{CO}_{2 \mathrm{en}(\mathrm{c}, \mathrm{s}, \mathrm{t})}+\mathrm{CO}_{2 \mathrm{nen}(\mathrm{c}, \mathrm{s}, \mathrm{t}) \text {. }} \mathbf{c}$ stands for and expresses the city, $\mathbf{s}$ sector and $\mathbf{t}$ time,the related year (Corsatea et al., 2019). Substituting gas for coal being used in the energy sector is of crucial importance in the simulation of environmental impact of $\mathrm{CO}_{2}$ emission data (Andreoni, Arto, Genty, Cantuche-Rueda and Villanueva, 2012). While reviewing literature; studies focused on environment, emission production, transport sector, and input-output analysis have been evaluated primarily. With the aim of showing the difference between this study and the other studies in literature, each study has been summarized using its field of study and method as base. Hence, limiting the content determining the distinctive points of this study and accuracy of the data base have been taken into consideration with the aim of getting more healthy results. 


\section{Theoretial Background}

Economics is defined as fulfilling unlimited human needs through scarce resources. Scarce resources are production factors which consist of natural resources, labor, capital, entrepreneur and technology. Among all these factors, natural resources are the factors in which scarcity is experienced the most (Mankiw, 1997, pp.3-5). Natural resources constitutes an important place in economics literature. Physiocracy states the agricultural production and land as the source of wealth, emphasizing the importance of natural resources. Agricultural production lost its importance with the approval of the thought of liberal economics. Industrialization and economic activities went up especially with the Industrial Revolution occured in the 18th Century, the use of coal rose and by this way mankind started to do great harm to the natural environment. Among all classical economic philosophers and thinkers, Adam Smith emphasized that the source of wealth was attained through capital accumulation, labour productivity and labour division rather than land; Malthus emphasized while population growth rate was geometrical, food supplies grew at an arithmetic rate and consequently natural resources would be limited and the danger of hunger would wait for the world; Ricardo emphasized that lands at different soil fertility would offer their owners different unearned rent income, and Mill emphasized destroying the natural resources would lead to the end of the world. Marx saw the destruction of natural resources and environment as the result of the capitalist system. Jevons asserted that coal which was the most important natural energy source of his age faced the risk of extinction and in case of this risk, natural resources like iron-steel were to be used, and thus, the cost of energy will increase. Marshall and Pigou handled the environmental problems caused by the negative externalities. Pareto stated that lessening the problems about market failures and about externalities would result in the optimal use of natural resources and the environment. During the Keynesian thought period; besides the economic growth, the use of natural resources also increased (Altınışık and Peker, 2011; Bocutoğlu, 2016; Dağdemir, 2003). Neoclassical economists, on the other hand, applied the models of economic growth which ignored the environment. Hotelling put forward the idea that a decrease in the supply of natural resources would bring out the demand related to the regulations of the use of these resources (Hotelling, 1931). The relationship between economic development and environmental pollution being studied by the economist Kuznets, who was awarded the Nobel prize, the Kuznets curve was formed. Kuznets curve shows that environmental pollution will increase besides the economic development but after a certain level of income, it will decrease (Kuznets, 1955, pp. 20-25).

Every activity for production and consumption depending on input-output correlation brings about the negative externalities. Wastes left in the ecological system and threatening the ecological structure release emission and therefore the dilemma between the economic development and environment arise (Baker, 2006, pp. 5-10). Economy, environment and ecological system should be evaluated as a whole for the sustainable development not to cause unsustainable environment.

Sustainability focuses on meeting the needs of all humanity at present and in future at the point of human activities integrated with nature. Today, the goals of sustainable transport have been evaluated as a whole in the context of economy, sociality, and environment (Litman, 2016, p.3; Önder, 2017, p.223). 


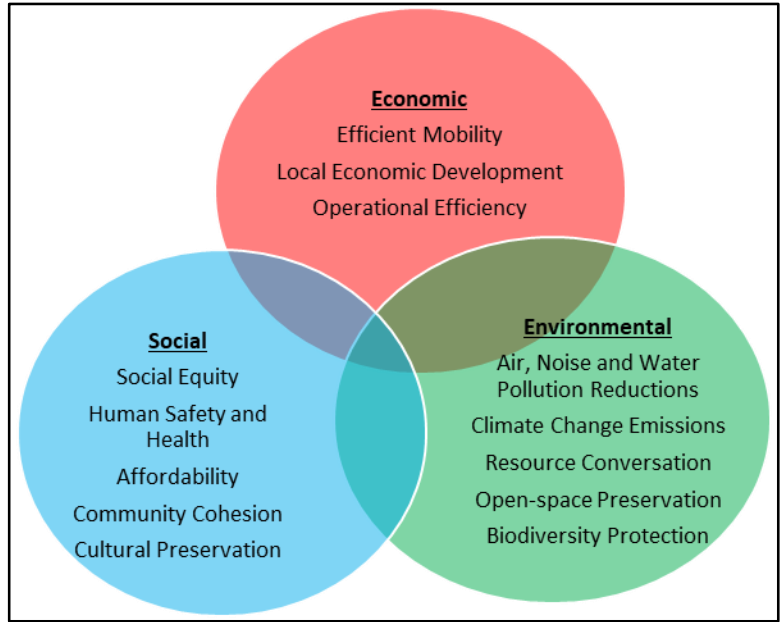

Figure 2: Sustainable Transport Goals

Resource: Litman, 2016, p.3.

Environmental economics does monetary analyses on the scarcity of natural resources and the effects of environmental pollution to economic welfare with micro and macro analyses. Ecological economics or green economics, being an interdisciplinary field of study researching the mutual interdependence of ecology and economy, aims at integrating the ecological cycle in nature into economic processes and takes the environment as the issue to be given the utmost importance (Ulucak, 2018; Van den Berg, 2001, p.16).

Ecological economy adopts to take precautions such as less production of environmentally hazardous substances; the use of environment protecting, environment friendly alternative products/substances, the use of treatment system without thinking the cost (Benli and Peker, 2018, pp.287-288; Peker, 2015). With limited transport capacity of the ecosystem, adapting oneself through threshold values analysis, carbon footprint analysis, life cycle analysis, environmental input-output analysis it has been tried to determine ecocide and to find solutions (Bennett, 2019, pp. 51-55; Hickel, 2020).

Day by day, it has become more and more important to contribute to support the evidence- based policy implementations, to research the reliable and comparable economic and environmental information making use of an extensive database (Arto et al., 2012). Hence, especially studies based on input-output analysis, paying attention to environmental values and assessing the $\mathrm{CO}_{2}$ release of sectors are included in the literature review which constitutes the basis of this study.

Machado, Schaeffer and Worrell, (2001), analyzed the energy use of sectors of Brazilian economy which are related to its international trade and their total impact on $\mathrm{CO}_{2}$ emissions. Carbon emissions of the Brazilian economy in 1995: inputs and outputs of non-energy goods consist of $10 \%-12 \%$ of total energy use and they are about $10 \%-14 \%$ of carbon inputs and outputs in non-energy goods. The finding has been reached that each dolar earned through export caused energy more than $40 \%$ and caused $\mathrm{CO}_{2}$ emission more than $56 \%$ than each dolar spent on import. In this framework, it reveals that energy use and carbon emissions should be taken into account while preparing international policies in Brazil. Alcántara and Padilla (2006), aimed at defining the key sectors responsible for $\mathrm{CO}_{2}$ emissions in Spanish economy. It has been determined that road transport, electricity and gas, base metal production, manufacturing non-metal mineral products, producing chemicals, producing coke from coal, refined petroleum products, nuclear fuel, wholesale and retail trade and agricultural sectors lead to both economic growth and income growth and therefore $\mathrm{CO}_{2}$ emissions are found more in these sectors. Tunç et al. (2006), as it has become crucial to calculate greenhouse gas emission in the framework of 
the Kyoto Protocol, they aim to determine the $\mathrm{CO}_{2}$ emission amount and to set forth the $\mathrm{CO}_{2}$ responsibility of Turkey. Concordantly, it is seen that manufacturing industry sector takes place on the top in $\mathrm{CO}_{2}$ emission production. $\mathrm{CO}_{2}$ responsibility is greater than released $\mathrm{CO}_{2}$ emissions; thus, it has been concluded that Turkey is explicitly $\mathrm{CO}_{2}$ importer. Alcántara and Padilla (2009), aimed at analyzing $\mathrm{CO}_{2}$ emissions that services sector in Spain produced. The conclusion that the $\mathrm{CO}_{2}$ emission of transport sector is quite high and other sectors cause more emission than their own final demand has been reached. It has emerged that wholesale and retail trade, hotel and restaurants, estate property, leasing and labour activities, public administration activities are primarily liable for $\mathrm{CO}_{2}$ emission increase recently. Cadarso, Gómez, López and Tobarra, (2010), had the purpose of studying the impact of freight transportation in Spain on total pollution. With this purpose, they used the input-output import table of Spain combining it with $\mathrm{CO}_{2}$ emission data. Results obtained have shown that the amount of total $\mathrm{CO}_{2}$ emission caused by international freight rose to 4,16 \% from 1995 to 2000. Faber, Proops and Wagenhals, (2012), made simulation scenarios using the input-output coefficients related to decreasing $\mathrm{CO}_{2}$ releases of sectors in German and British economies. According to these scenarios, it will be possible to decrease $\mathrm{CO}_{2}$ emissions in case of making technological changes to generate electricity, changing the general consumption patterns (changing hydrocarbons with carbohydrates), preferring the options about the expectations for passenger transport and freight changes. Çağatay and Özeş (2013), analyzed the relationship between the transport sector and alternative types of energy in terms of both the economic impact and the emission impact. They suggested five scenario proposals making use of input-output table for alternative energy substitution. The finding was reached that $\mathrm{CO}_{2}$ emissions would be much less and environmental income would be much higher when the electrical energy was used. It was determined that sectors based on imported input were highly affected by substitute for electricity. Arto et al. (2014), used two different database (World Input-Output Database-WIOD and Global Trade Analysis Project: Multi Region Input-Output Analysis-GTAPMRIO) to calculate carbon foot print caused by global emissions which takes place in the final demand of 43 countries whose data was published in WIOD. Differences in data clusters of the U.S.A the Public Republic of China, Russia and India explain nearly $50 \%$ of the differences in the carbon foot print. Taşdoğan and Taşdoğan (2014), identifying the key sectors of Turkey, targeted to determine the emission impacts of these sectors to arise according to the environmental satellite accounts. According to the findings reached, it was determined that emission impacts of road transport, marine transport, airline transport, agriculture, coal, food, textile, wood, coking coal, chemicals, plastic, manufacturing other non-metal mineral products, base metal, construction, other service facilities with electricity, gas, steam and water production sectors are more than other sectors. Liu, Wang, Zhao, Zhang and Zhang (2015), were in the aim of determining the $\mathrm{CO}_{2}$ emissions released after the intersectoral corporation in industry. In the study, it appears that $\mathrm{BLj}$ (normalized total backward $\mathrm{CO}_{2}$ linkages coefficients) impacts of industry produce 81.58 million tons of $\mathrm{CO}_{2}$ and $\mathrm{FLi}$ (normalized total forward $\mathrm{CO}_{2}$ linkages coefficients ) 89,71million tons. Arévalo-Rodríguez, Braza-Sánchez and Cansino, (2015), analyzed the role of renewable energy sources in Spain in balancing $\mathrm{CO}_{2}$ emissions as an important component. In the study, 35 productive sectors were focused. It was concluded that renewable energy sources harm the driving sources of $\mathrm{CO}_{2}$ emissions. Buckley, Boland, Piantadosi, Reynolds and Weinstein, (2015), using EEIO-environmentally extended input-output, they researched the environmental impact of weekly food consumption in houses with different socio-economic conditions in Australia put in order according to their income level. The result was obtained that household with higher level of income cause more environmental pollution than the one with low level. They asserted that it would reduce the negative effects causing environmental pollution to substitute the consumption of animal products, processed food, and oil with fruit and vegetables. Andrei, Cristina, Mieila, Nica and Popescu (2016), through Romania Gross 
Domestic Product, they aimed to put forth a possible causal connection between different variables in terms of energy production and consumption and to tax the environmentally harmful elements. At the end of the study, a relation was made between bringing the prosperity and taxing environment pollutants through Gross Domestic Product. Hadjikakou (2016), analyzed the environmental impacts of food consumption of household in Australia in their lifetime. The result was obtained that the household realized $35 \%$ water use,39\% energy use,33 $\% \mathrm{CO}_{2}$ equivalent and $35 \%$ land use on average in life cycle. Chatellier and Sheinbaum-Pardo (2017), intended to predict a scenario for 2026, and to calculate energy systems and greenhouse gas emissions of Mexico. In this framework, $\mathrm{CO}_{2}$ emission values were calculated over the total impact of all sectors. Through this study, it was concluded that final demand changes in sectors of freight and passenger transportation, air freight, energy production, iron-steel, chemistry and agriculture are big on total emissions. Similarly, it was concluded that final demand changes of other sectors have great impact on the emissions of these sectors. Liu and Fan (2017), intended to calculate $\mathrm{CO}_{2}$ emissions of 77 countries according to their sectors. Within the scope of economic benefit principle, their intention was to develop a model to calculate $\mathrm{CO}_{2}$ emissions using value-added-based accounting. In the end, the implementation of Clean Development Mechanism projects was proposed to make global carbon emission less. Renner (2017), intended to analyze the wealth effect of carbon taxes over income distribution applied in Mexico. Input-output model was simulated with the data for household. The conclusion was reached that taxes had to be enlarged as to include natural gas and other greenhouse gases $\left(\mathrm{CH}_{4}\right.$, $\mathrm{N}_{2} \mathrm{O}$ ) because of the increase in food price. Mach, Ščasný and Weinzettel (2018), targeted to calculate the emission rates household in the Czech Republic produced directly and indirectly. For this purpose, they did analysis constructing Environmentally Extended Input-Output-EEIO table.It was inferred that a great part of emissions were due to electricity,heating,food and transportation and the flexibility of emission fee was approximately 0,8 . Tokito (2018), aimed at determining the emissions which important sectors in global supply chain networks produce, which is related to the demand for the last transport equipment of the U.S.A, China, Germany, Japan and France through the input-output clustering analysis and structural path betweenness analysis he did. He reached the conclusion that global supply chain networks have higher emission. Baumert, Kander, Kulionis, Nielsen and Jiborn (2019), intended to research if it is valid or not when the change in the emission production depending on outsourcing in developed and developing countries is adjusted according to technological differences. Firstly, it was concluded that the size of outsource is considerably smaller than the ones in the previous studies; secondly, there is no a clear difference between developing and developed countries. While emissions increased with outsourcing between the years 1995 and 2009 because the tendency of the U.S.A, England, Canada and Australia was towards goods with high-density carbon in import and low-density carbon in export, other developed countries kept positive emission trade balance and China, on the other hand, is an important source in the production of emission. Vita et al. (2019), intended to link local sustainability visions throughout Europe to global results and to lessen carbon foot print. They constructed Environmentally Extended Multi Regional Input-Output table and they applied this to 19 scenarios. In the end, it was foreseen that energy-sourced carbon foot print would be reduced at the approximate level of 18 $\%$ of service sector, $3 \%$ of clothing and electrical appliances sector, $9 \%-26$ of transport sector, $4 \%$ of food sector, $5 \%-14 \%$ housing sector. Bednar-Friedl, Muñoz, Nabernegg, Titz and Vogel (2019), aimed to determine the efficient conditions in reducing the carbon emissions which construction, public health and transport sectors produce in Austria. Computable General Equilibrium and Multi-Regional Input-Output model-MRIO were used together. It was predicted that taxing would be effective in reducing the emissions based on consumption in the construction sector, compulsory energy efficiency improvements in the public health sector and reducing the production and consumption based emissions in the transport sector. Chen, Huang 
and Sun (2020), aimed at analyzing the $\mathrm{CO}_{2}$ emissions of the sectors taking place in the international trade of Russia. The finding was reached that the industry sector based on the traditional manufacture and the industry sector based on the modern technology played an important role in the $\mathrm{CO}_{2}$ emission of Russia, $\mathrm{CO}_{2}$ emission which modern industry sector import includes rose. Schmidt, Tukker and Wood (2020), aimed to synthesize a few basic precautions for international consumption-based global carbon accounts aggregated in 35 sectors of 43 countries whose data were published in WIOD. Global multi-regional input-output carbon emissions were used. In classical production-based accounts and related policy making, harmonizing the current data was shown to be a prominent factor in global carbon foot print and consumption-based carbon accounts. Benedict-Kemp, Campiglio, Cahen-Fourot, Dawkins and Godin (2020), determined to specify forward link serving sectors constructing an inputoutput table with examples from 18 European countries. For this purpose, they created national inverted pyramid networks using input-output tables. They reached the conclusion that mining was the top forward linking sector and this was internationally consistent through cluster analysis. Brouwer, Eamen and Razavi (2020), using supply-sided input-output tables to analyze the indirect economic impacts of water-supply restrictions depending on climate and political changes, they aimed to specify the interregional development. For this purpose, applying two different water supply-restriction scenarios to the river basin of Saskatchewan including three states, they analyzed the economic impacts of the scenarios one by one. Finally, it was seen that the economic loss in case of water shortage depending on climate change could be reduced by nearly $50 \%$.

When evaluating the literature, it is seen that most part of the studies conducted is in the form of analyzing the environmental impacts of $\mathrm{CO}_{2}$ emissions produced depending on sectoral activities on the basis of countries. These studies depend on evaluations carried out making use of input-output analysis constituted with data obtained from different worldwide database with the production of different simulations and scenarios. In the content of the study, conclusions about carbon foot print of countries, sectorally produced emission values, specifying emission intensive sectors, specifying the emission rates key sectors produce and the role of renewable energy sources in balancing the emission rates were made. Finally, the conclusion has been reached that the leading sectors in the emission production were transport sectors and energyintensive sectors.

\section{Methodology and Data Analysis}

Input-output analysis is based on Quesnay's Economic Table "Tableau économique" (Quesnay, 1758) and Walras's general equilibrium theory (Walras, 1954). Leontief, the Nobelprized economist, constructed the first input-output table and model indicating the intersectoral link in the American economy (Leontief, 1936). Later on, Rasmussen reached the total linkage coefficients creating Leontief inverse matrix which constitutes the base of this study, and normalized these coefficients and made the definition of key sector (Rasmussen, 1956). Chenery and Watanabe, on the other hand, calculating the impacts of direct backward linkages and direct forward linkages via the technological matrix, made the definition of key sector calculated through these impacts and they first realized the process of aggregation for the inputoutput table. Hirschman made use of Chenery and Watanabe's approach to the key sector and advanced the model of unbalanced growth (Chenery and Watanabe, 1958; Hirschman, 1978). Hazari reinterpreted Rasmussen's Index of Power of Dispersion and Index of Sensitivity of

Dispersion, assessed the coefficient of variation and accepted the activities over the mean value as the key sector (Hazari, 1970). The linkage analysis of the sectors are based on HEM to analyze the effect of the changes in structure on an economy (Schultz, 1977). This analysis was promoted by Cella (1984), who proposed backward linkage, forward linkage, and total linkage among the sectors. Leontief advanced the model of (Environmentally Extended 
Input-Output Analysis) EEIOA indicating the case when the third sector is included in two sectors with the aim of decontaminating the dirt caused by these two sectors. In this way, he showed that as a result of final demand; labour, cost, intermediate consumption, decontamination activities needed for the production in sectors and environmental problems can be analyzed in the framework of economy (Leontief, 1970). Miller ve Blair added the unwanted environmental externalities in the classical input-output model and explained how to use the Extended Environmental Input-Output Model (Blair and Miller, 2009).

In this study, environmental input-output table has been improved bringing input-output table (Korum, 1963, pp.9-13; TÜIK, 2020) ${ }^{1}$ including intersectoral monetary operations in economy together with $\mathrm{CO}_{2}$ emission data. EEIOA has been used via the table constructed (Arto, Genty and Neuwahl, 2012; Newton, Prasad, Sproul and White, 2019, pp.122-123;). Environmentally extended input-output analysis shows the indirect environmental impacts caused by domestic and foreign production. Thus, EEIOA provides the analyses for ecological footprint, greenhouse gas emissions, assessing the energy use (Du, Lee, Li, Wang and Wang, 2019; De Vries, Dietzenbacher, Los, Stehrer and Timmer, 2015).

WIOD greenhouse gas emissions $\left(\mathrm{CO}_{2}, \mathrm{CH}_{4}, \mathrm{~N}_{2} \mathrm{O}\right)$ contain the environmental satellite accounts related to including energy, soil, equipment and water (Arto et al., 2012; Corsatea et al., 2019, pp.16-17, 24). In WIOD database, the most up to date format of $\mathrm{CO}_{2}$ emission data belongs to the year 2016. However,the most current data for the input-output tables of Turkey belongs to the year 2014. Since the objective of our study is to account $\mathrm{CO}_{2}$ emissions which the change in the final demand cause specifically in the transport sector and WIOD input-output tables are figured out on current period million dolar basis, environmental satellite accounts in which $\mathrm{CO}_{2}$ emission data of the same year takes place have been used (Corsatea et al., 2019; EU SCIENCE UP, 2019; WIOD, 2016). In the content of the study, WIOD input-output tables of Turkey for the year 2014 have been used with the aim of reaching comparable and healthy results. In database, air emission value data of WIOD satellite database of Turkey takes place in one column. Therefore, procedures followed for the purpose of producing an accurate environmental input-output table are as follows:

In WIOD database, input-output table has been constructed adding the output table of the imported input coefficients $\left(\mathrm{A}^{\mathrm{m}}\right)$ to domestic input coefficients $\left(\mathrm{A}^{\mathrm{d}}\right)$ of each sector (Küçükkiremitçi and Güler, 2020, p.128-129). Formula (1) has been used for this purpose.

$$
\mathrm{A}=\mathrm{Am}+\mathrm{Ad}
$$

The reason that the input-output table of importation is included in accounting is some of the imports are intermediate inputs and produce $\mathrm{CO}_{2}$ emission both during the process of becoming outputs and in the process after they have become outputs (Dietzenbacher and Los, 2000; Leontief, 1946; Leontief, 1953a, Leontief 1953b; Liu et al., 2015, pp.917-920).

Secondly, technical coefficient matrix is calculated making use of input-output table constructed. To achieve this goal, input coefficients of each sector are obtained by formula (2) (Güler, 2019, pp.84-85; Leontief, 1986, pp.22-23) .

$$
a_{i j}=\frac{x_{i j}}{X_{i}}
$$

Although there exist 0 coefficient sectors in the domestic input-output table released by WIOD, values of the same sectors are included in accounting as they do not equal 0 in the import input-output table (WIOD, 2016). However, after the technological matrix has been

\footnotetext{
${ }^{1}$ Among the hypotheses of input-output model; input rate, capital ratio,import rate and rates like these have been accepted to be constant.For this reason,coefficients obtained in 2014 input-output table released most recently have been used to assess total backward and total forward $\mathrm{CO}_{2}$ linkage coefficients of one unit production result of each sector.
} 
constructed for sectors having 0 coefficient not to cause malfunctioning in accounting, both rows and columns have been deleted.Thus, the 46x46 matrix has been constructed.

$\left[\begin{array}{ccc}a 11 & \cdots & a 146 \\ \vdots & \ddots & \vdots \\ a 461 & \cdots & a 4646\end{array}\right]$

Thirdly, Leontief Inverse Matrix has been constructed. Production values needed for 46 final demand vectors and 46 productive sectors are shown in the following formulas. Here, $\mathbf{x}$ stands for the production value of sectors, a stands for technical coefficients and $\mathbf{y}$ final demand vector.

$$
\begin{gathered}
X_{1}=A_{11} X_{1}+A_{12} X_{2}+\cdots+A_{146} X_{46}+Y_{1} \\
X_{2}=A_{21} X_{1}+A_{22} X_{2}+\cdots+A_{246} X_{46}+Y_{2} \\
\cdot \\
\cdot \\
X_{46}=A_{461} X_{1}+A_{46} X_{2}+\cdots+A_{4646} X_{46}+Y_{46}
\end{gathered}
$$

By this way, the input-output equation $\mathrm{X}=\mathrm{AX}+\mathrm{Y}$ or equation $\mathrm{Y}=(1-\mathrm{A}) \mathrm{X}$ of an economy is obtained. Both sides: (1-A $)^{-1}$ to leave $X$ alone. This case can be expressed in the modeling below. Thus, total output is formulated as $\mathrm{X}=(\mathrm{I}-\mathrm{A})^{-1} \mathrm{Y}$. Coefficients of Leontief Inverse Matrix (I-A) $)^{-1}$ show the coefficients required for one single unit, direct or indirect production of sectors for the final demands. Matrix display of the formed equation is as follows:

$$
\left|\begin{array}{c}
x_{1} \\
x_{2} \\
\cdot \\
\cdot \\
\cdot \\
x_{46}
\end{array}\right|=\left|\begin{array}{cccc}
\left(1-a_{11}\right) & -a_{12} & \ldots & -a_{146} \\
-a_{21} & \left(1-a_{22}\right) & \ldots & -a_{246} \\
\cdot & \cdot & \ldots & \cdot \\
\cdot & \cdot & \ldots & \cdot \\
\cdot & \cdot & \ldots & \cdot \\
-a_{461} & -a_{462} & \ldots & \left(1-a_{4646}\right)
\end{array}\right|
$$

As the fourth step, $\mathrm{CO}_{2}$ emission vector has been constructed to analyze the $\mathrm{CO}_{2}$ emission of sectors, which is the aim of the study, as a result of the final demand increase. $\mathrm{CO}_{2}$ emission data released in WIOD database show the emerging $\mathrm{CO}_{2}$ emission amount resulted from the total production (denominated in one million dollars). In this regard, in the analysis we have carried out, primarily $\mathrm{CO}_{2}$ emissions every sector produce per unit (1 dollar) being accounted separately ( just as in formula 3 ), a new column has been constructed.

$\tau_{i}=\frac{\tau_{\mathrm{i}}}{X_{\mathrm{i}}}$

$\tau_{\mathrm{i}}=\mathrm{CO}_{2}$ emission release resulted from one single unit production of the 1 st sector (1\$)

$\tau_{\mathrm{i}}=\mathrm{CO}_{2}$ emission arising as a result of the total production of the 1st sector (kiloton)

$\mathrm{X}_{\mathrm{i}}=$ total output of the first sector (million dolar)

Afterwards, a vector of 46x1 has been established by $\tau$ i coefficients accounted one by one for each sector. Leontief inverse matrix is multiplied by the newly-constructed vector and formula (4) has been reached (Küçükkiremitçi, 2013, pp.18-19).

$$
\text { c. } X=\tau .(I-A)-1 Y
$$

Environmental Leontief inverse matrix has been constructed using formula (4) and shown below (Güler, 2020, pp. 39-48; Küçükkiremitçi, 2011; Leontief, 1949, pp.277-279; Liu et al., 2015, pp.917-918). 


$$
\left|\begin{array}{c}
\tau_{1} \\
\tau_{2} \\
\cdot \\
\cdot \\
\tau_{46}
\end{array}\right|\left|\begin{array}{c}
x_{1} \\
x_{2} \\
\cdot \\
\cdot \\
x_{46}
\end{array}\right|=\left|\begin{array}{cccc}
\tau_{1} \\
\tau_{2} \\
\cdot \\
\cdot \\
\tau_{46}
\end{array}\right|\left|\begin{array}{cccc}
\left(1-a_{11}\right) & -a_{12} & \ldots & -a_{146} \\
-a_{21} & \left(1-a_{22}\right) & \ldots & -a_{246} \\
\cdot & \cdot & \ldots & \cdot \\
\cdot & \cdot & \ldots & \cdot \\
-a_{461} & -a_{462} & \ldots & \left(1-a_{4646}\right.
\end{array}\right|\left|\begin{array}{c}
y_{1} \\
y_{2} \\
\cdot \\
\cdot \\
y_{46}
\end{array}\right|
$$

In this context, total backward $\mathrm{CO}_{2}$ linkages coefficients of sectors are reached through sum of each column of Leontief inverse matrix one by one and total forward $\mathrm{CO}_{2}$ linkages coefficients of sectors are reached through sum of each row one by one. Normalized total backward $\mathrm{CO}_{2}$ linkages coefficients $\left(\mathrm{BL}_{\mathrm{j}}\right)$ of the relevant sector are assessed dividing the total backward $\mathrm{CO}_{2}$ linkages coefficient of the relevant sector by the arithmetic mean of total backward $\mathrm{CO}_{2}$ linkages coefficients of all sectors. $\left(\mathrm{BL}_{\mathrm{j}}\right)$, stands for the $\mathrm{CO}_{2}$ emission caused by the production increase relevant sector has created in all sectors following its one-dollar final demand increase.

Normalized total forward $\mathrm{CO}_{2}$ linkages coefficients $\left(\mathrm{FL}_{\mathrm{i}}\right)$ of the relevant sector are assessed dividing the total forward $\mathrm{CO}_{2}$ linkages coefficient of the relevant sector by the arithmetic mean of total forward $\mathrm{CO}_{2}$ linkages coefficients of all sectors. $\left(\mathrm{FL}_{\mathrm{i}}\right)$ stands for the $\mathrm{CO}_{2}$ emission resulted from the production increase all sectors have created in all sectors following their one-dollar final demand increase.

Table 1: One Single Unit CO2 Emission of all Sectors ${ }^{2}$ in Turkey, (Bj), (FLi) (Total Backward Carbon Linkage Rank)

\begin{tabular}{|c|c|c|c|c|c|c|}
\hline & \multicolumn{2}{|c|}{$\mathrm{CO}_{2}$ Emission kt/milion dollar } & \multicolumn{2}{|l|}{ BLj } & \multicolumn{2}{|l|}{$\mathbf{F L}_{\mathbf{i}}$} \\
\hline & Sectors & Coefficient & Sectors & $\begin{array}{l}\text { Coeffici } \\
\text { ent }\end{array}$ & Sectors & Coefficient \\
\hline 1 & D35 & 3,0853 & D35 & 10,2080 & D35 & 21,7659 \\
\hline 2 & $\mathrm{C} 23$ & 2,9358 & $\mathrm{C} 23$ & 6,3886 & $\mathrm{C} 23$ & 9,1601 \\
\hline 3 & M72 & 1,8579 & M72 & 3,4138 & $\mathrm{C} 24$ & 3,4429 \\
\hline 4 & $\mathrm{C} 24$ & 0,4530 & $\mathrm{C} 24$ & 2,4623 & M72 & 3,2055 \\
\hline 5 & H51 Air Transport & 0,3437 & $\mathrm{C} 25$ & 1,2612 & $\begin{array}{l}\text { H49 Land transport } \\
\text { and transport via } \\
\text { pipelines }\end{array}$ & 1,1895 \\
\hline 6 & E37-E39 & 0,2837 & $\mathrm{C} 17$ & 1,1235 & $\mathrm{C} 20$ & 1,0705 \\
\hline 7 & $\mathrm{C} 19$ & 0,1943 & C31_C32 & 1,1010 & $\mathrm{C} 19$ & 1,0287 \\
\hline 8 & $\begin{array}{l}\text { H49 Land transport } \\
\text { and transport via } \\
\text { pipelines }\end{array}$ & 0,1356 & $\mathrm{~F}$ & 1,0456 & H51 Air Transport & 0,7840 \\
\hline 9 & $\mathrm{C} 20$ & 0,1304 & $\mathrm{C} 29$ & 0,9554 & E37-E39 & 0,5892 \\
\hline 10 & C31-C32 & 0,1070 & C19 & 0,9520 & $\mathrm{C} 17$ & 0,3925 \\
\hline 11 & H50 Water transport & 0,1068 & $\mathrm{C} 28$ & 0,9468 & H50 Water transport & 0,3234 \\
\hline 12 & $\mathrm{C} 17$ & 0,1010 & E37-E39 & 0,9171 & $\mathrm{~N}$ & 0,2607 \\
\hline 13 & $\mathrm{C} 30$ & 0,0919 & $\mathrm{C} 27$ & 0,9166 & $\mathrm{~B}$ & 0,2272 \\
\hline 14 & A03 & 0,0871 & H51 Air Transport & 0,8929 & C31_C32 & 0,2011 \\
\hline 15 & $\mathrm{C} 25$ & 0,0783 & $\mathrm{C} 22$ & 0,8017 & $\mathrm{C} 25$ & 0,1966 \\
\hline 16 & $\mathrm{~A} 02$ & 0,0707 & $\mathrm{C} 16$ & 0,7703 & A01 & 0,1890 \\
\hline 17 & $\mathrm{~N}$ & 0,0635 & C30 & 0,7673 & $\mathrm{C} 30$ & 0,1837 \\
\hline 18 & $\mathrm{C} 16$ & 0,0625 & $\mathrm{C} 20$ & 0,7422 & $\mathrm{C} 10-\mathrm{C} 12$ & 0,1788 \\
\hline 19 & $\mathrm{C} 10-\mathrm{C} 12$ & 0,0528 & $\mathrm{C} 18$ & 0,6329 & $\mathrm{~A} 03$ & 0,1528 \\
\hline 20 & A01 & 0,0486 & $\mathrm{~B}$ & 0,6255 & $\mathrm{~A} 02$ & 0,1508 \\
\hline 21 & $\mathrm{~F}$ & 0,0469 & $\mathrm{C} 26$ & 0,5608 & $\mathrm{C} 16$ & 0,1507 \\
\hline 22 & $\mathrm{C} 27$ & 0,0464 & Q & 0,5288 & C13-C15 & 0,1242 \\
\hline 23 & $\mathrm{~B}$ & 0,0425 & C13-C15 & 0,5249 & $\mathrm{C} 22$ & 0,1218 \\
\hline
\end{tabular}

\footnotetext{
${ }^{2}$ In order for all the sectors to be seen on the table; the codes of other sectors except the names of land, air, water transport sectors have been written. For sector names, see Appendix
} 


\begin{tabular}{|c|c|c|c|c|c|c|}
\hline 24 & $\mathrm{C} 22$ & 0,0407 & E36 & 0,5246 & $\mathrm{C} 27$ & 0,1157 \\
\hline 25 & $\mathrm{C} 18$ & 0,0353 & O84 & 0,5118 & G45 & 0,1031 \\
\hline 26 & $\mathrm{C} 45$ & 0,0345 & $\mathrm{C} 10-\mathrm{C} 12$ & 0,4794 & $\mathrm{~F}$ & 0,1029 \\
\hline 27 & $\mathrm{C} 28$ & 0,0291 & I & 0,4766 & $\mathrm{C} 18$ & 0,0906 \\
\hline 28 & K65 & 0,0272 & $\begin{array}{l}\text { H49 Land transport } \\
\text { and transport via } \\
\text { pipelines }\end{array}$ & 0,4500 & $\mathrm{C} 29$ & 0,0876 \\
\hline 29 & G45 & 0,0269 & G45 & 0,4331 & $\mathrm{C} 26$ & 0,0795 \\
\hline 30 & C13-C15 & 0,0263 & R_S & 0,3670 & $\mathrm{C} 28$ & 0,0766 \\
\hline 31 & $\mathrm{C} 26$ & 0,0213 & H50 Water transport & 0,3619 & K65 & 0,0525 \\
\hline 32 & K66 & 0,0168 & K66 & 0,3240 & K66 & 0,0364 \\
\hline 33 & R_S & 0,0111 & $\mathrm{~N}$ & 0,3137 & G46 & 0,0312 \\
\hline 34 & J62-J63 & 0,0107 & J61 & 0,3035 & R_S & 0,0274 \\
\hline 35 & E36 & 0,0106 & P85 & 0,2872 & E36 & 0,0220 \\
\hline 36 & G46 & 0,0047 & L68 & 0,2795 & J62_J63 & 0,0215 \\
\hline 37 & Q & 0,0042 & A03 & 0,2775 & H52 & 0,0152 \\
\hline 38 & H52 & 0,0033 & A01 & 0,2749 & M74-M75 & 0,0094 \\
\hline 39 & P85 & 0,0025 & M74-M75 & 0,2630 & K64 & 0,0091 \\
\hline 40 & P85 & 0,0018 & $\mathrm{~A} 02$ & 0,2603 & Q & 0,0081 \\
\hline 41 & Q84 & 0,0017 & G46 & 0,2463 & G47 & 0,0065 \\
\hline 42 & M74-M75 & 0,0015 & G47 & 0,2306 & P85 & 0,0047 \\
\hline 43 & I & 0,0013 & H52 & 0,2212 & L68 & 0,0039 \\
\hline 44 & G47 & 0,0013 & K65 & 0,2032 & I & 0,0037 \\
\hline 45 & L68 & 0,0010 & K64 & 0,1879 & O84 & 0,0031 \\
\hline 46 & J61 & 0,0000 & J62_J63 & 0,1836 & J61 & 0,0000 \\
\hline
\end{tabular}

Resource: EU SCIENCE UP,2019; WIOD, 2016; Corsatea and others were created by the author using 2019 data

In Table 1,when air, water and land transport and transport via pipelines are all analyzed altogether, one unit $\mathrm{CO}_{2}$ emission amount takes place in the fourth row with $0,5861 \mathrm{kt} / \mathrm{million}$ dollar; $\mathrm{BLj} 1,7048$ kiloton (kt) equivalent of $\mathrm{CO}_{2}$ and $\mathrm{FLi} 2,2969$ kiloton equivalent of (kt) $\mathrm{CO}_{2}$ take place in the fifth row. 
Table 2: Partial Total Backward $\mathrm{CO}_{2}$ Linkages Coefficients of Air, Water, Land Transport Sectors ${ }^{3}$

\begin{tabular}{|c|c|c|c|c|c|c|}
\hline & \multicolumn{2}{|c|}{ Air Transport } & \multicolumn{2}{|c|}{ Water transport } & \multicolumn{2}{|c|}{ Land transport and transport via pipelines } \\
\hline & Sectors & Coefficient & Sectors & Coefficient & Sectors & Coefficient \\
\hline 1 & H51 & 0,3617 & $\mathrm{H} 50$ & 0,1165 & H49 & 0,1570 \\
\hline 2 & D35 & 0,0766 & D35 & 0,0359 & D35 & 0,0496 \\
\hline 3 & $\mathrm{C} 19$ & 0,0247 & C19 & 0,0145 & $\mathrm{C} 19$ & 0,0178 \\
\hline 4 & $\mathrm{H} 49$ & 0,0153 & H49 & 0,0135 & $\mathrm{C} 23$ & 0,0115 \\
\hline 5 & $\mathrm{C} 23$ & 0,0148 & $\mathrm{C} 23$ & 0,0087 & $\mathrm{C} 24$ & 0,0087 \\
\hline 6 & $\mathrm{C} 24$ & 0,0063 & $\mathrm{C} 24$ & 0,0052 & H51 & 0,0038 \\
\hline 7 & $\mathrm{C} 20$ & 0,0035 & H51 & 0,0039 & $\mathrm{C} 20$ & 0,0025 \\
\hline 8 & $\mathrm{~N}$ & 0,0032 & $\mathrm{~N}$ & 0,0027 & $\mathrm{~N}$ & 0,0018 \\
\hline 9 & $\mathrm{C} 30$ & 0,0022 & $\mathrm{C} 20$ & 0,0023 & G45 & 0,0017 \\
\hline 10 & $\mathrm{~B}$ & 0,0022 & $\mathrm{~B}$ & 0,0013 & $\mathrm{~B}$ & 0,0016 \\
\hline 11 & G45 & 0,0015 & $\mathrm{C} 30$ & 0,0012 & H50 & 0,0014 \\
\hline 12 & H50 & 0,0013 & G45 & 0,0009 & $\mathrm{C} 29$ & 0,0006 \\
\hline 13 & C10-C12 & 0,0010 & C10-C12 & 0,0007 & $\mathrm{C} 17$ & 0,0005 \\
\hline 14 & $\mathrm{C} 17$ & 0,0009 & A01 & 0,0005 & $\mathrm{C} 22$ & 0,0004 \\
\hline 15 & C13-15 & 0,0009 & H52 & 0,0004 & H52 & 0,0003 \\
\hline 16 & $\mathrm{~A} 01$ & 0,0008 & $\mathrm{C} 17$ & 0,0004 & C13-15 & 0,0003 \\
\hline 17 & H52 & 0,0005 & $\mathrm{C} 28$ & 0,0003 & C10-C12 & 0,0003 \\
\hline 18 & K64 & 0,0003 & $\mathrm{C} 29$ & 0,0002 & $\mathrm{C} 27$ & 0,0003 \\
\hline 19 & $\mathrm{C} 27$ & 0,0003 & C13-15 & 0,0002 & $\mathrm{C} 18$ & 0,0003 \\
\hline 20 & $\mathrm{C} 25$ & 0,0003 & $\mathrm{C} 27$ & 0,0002 & A01 & 0,0002 \\
\hline 21 & $\mathrm{C} 22$ & 0,0002 & $\mathrm{C} 25$ & 0,0002 & C31-C32 & 0,0002 \\
\hline 22 & C18 & 0,0002 & $\mathrm{C} 22$ & 0,0002 & $\mathrm{C} 25$ & 0,0002 \\
\hline 23 & C29 & 0,0002 & C18 & 0,0001 & C16 & 0,0002 \\
\hline 24 & G46 & 0,0002 & G46 & 0,0001 & C30 & 0,0002 \\
\hline 25 & K66 & 0,0002 & K65 & 0,0001 & G46 & 0,0001 \\
\hline 26 & C26 & 0,0001 & $\mathrm{C} 26$ & 0,0001 & $\mathrm{C} 28$ & 0,0001 \\
\hline 27 & K65 & 0,0001 & C31-C32 & 0,0001 & $\mathrm{~F}$ & 0,0001 \\
\hline 28 & C28 & 0,0001 & R_S & 0,0001 & $\mathrm{C} 26$ & 0,0001 \\
\hline 29 & C31-C32 & 0,0001 & $\mathrm{~F}$ & 0,0001 & E37-E39 & 0,0001 \\
\hline 30 & I & 0,0001 & C16 & 0,0001 & K64 & 0,0001 \\
\hline 31 & $\mathrm{~F}$ & 0,0001 & E37-E39 & 0,0000 & M72 & 0,0001 \\
\hline 32 & R_S & 0,0001 & M72 & 0,0000 & $\mathrm{~A} 02$ & 0,0001 \\
\hline 33 & $\mathrm{C} 16$ & 0,0001 & K64 & 0,0000 & M74-M75 & 0,0000 \\
\hline 34 & M72 & 0,0001 & M74-M75 & 0,0000 & K65 & 0,0000 \\
\hline 35 & E37-E39 & 0,0001 & $\mathrm{~A} 02$ & 0,0000 & R_S & 0,0000 \\
\hline 36 & M74-M75 & 0,0001 & K66 & 0,0000 & K66 & 0,0000 \\
\hline 37 & A02 & 0,0001 & I & 0,0000 & L68 & 0,0000 \\
\hline 38 & A03 & 0,0000 & G47 & 0,0000 & I & 0,0000 \\
\hline 39 & L68 & 0,0000 & E36 & 0,0000 & G47 & 0,0000 \\
\hline 40 & G47 & 0,0000 & L68 & 0,0000 & E36 & 0,0000 \\
\hline 41 & E36 & 0,0000 & A03 & 0,0000 & J62-J63 & 0,0000 \\
\hline 42 & J62-J63 & 0,0000 & J62-J63 & 0,0000 & $\mathrm{~A} 03$ & 0,0000 \\
\hline 43 & $\mathrm{Q}$ & 0,0000 & $\mathrm{Q}$ & 0,0000 & Q & 0,0000 \\
\hline 44 & $\mathrm{P} 85$ & 0,0000 & P85 & 0,0000 & P85 & 0,0000 \\
\hline 45 & O84 & 0,0000 & O84 & 0,0000 & O84 & 0,0000 \\
\hline 46 & J61 & 0,0000 & J61 & 0,0000 & J61 & 0,0000 \\
\hline
\end{tabular}

Resource: EU SCIENCE UP, 2019; WIOD, 2016; Corsatea and others were created by the author using 2019 data

As seen in Table 2,total backward $\mathrm{CO}_{2}$ linkage coefficient, when partially evaluated, the greatest coefficient of sectors of air, water and land transport belongs to their own sectors as required by the accounting technique of the method. Of sectors which these three sectors are

\footnotetext{
${ }^{3}$ Evaluation of Total backward $\mathrm{CO}_{2}$ linkage coefficient on the basis of the related sector's column
} 
partially total backwarded; electricity, gas, steam and air conditioning supply sectors come the second, in the third rank is manufacture of coke and refined petroleum products sector.

The $\mathrm{CO}_{2}$ emission order created by the inputs they provide from each other for the realization of air, land and water transportation is as follows: land transport is in fourth and water transport is in twelfth place for air transportation; land transport is in fourth and air transport in in seventh place for water transport; air transport is in sixth and water transport is in eleventh place for land transport.

Table 3: Partial Total Forward $\mathrm{CO}_{2}$ Linkages Coefficients of Air, Water, Land Transport ${ }^{4}$

\begin{tabular}{|c|c|c|c|c|c|c|}
\hline & \multicolumn{2}{|c|}{ Air Transport } & \multicolumn{2}{|c|}{ Water transport } & \multicolumn{2}{|c|}{ Land transport and transport via pipelines } \\
\hline & Sectors & Coefficient & Sectors & Coefficient & Sectors & Coefficient \\
\hline 1 & H51 & 0,3617 & H50 & 0,1165 & H49 & 0,1570 \\
\hline 2 & $\mathrm{O} 84$ & 0,0098 & G47 & 0,0053 & H52 & 0,0298 \\
\hline 3 & J61 & 0,0057 & $\mathrm{C} 19$ & 0,0048 & $\mathrm{C} 19$ & 0,0226 \\
\hline 4 & H52 & 0,0049 & $\mathrm{C} 24$ & 0,0030 & $\mathrm{C} 29$ & 0,0204 \\
\hline 5 & G46 & 0,0043 & $\mathrm{C} 25$ & 0,0028 & $\mathrm{C} 31-\mathrm{C} 32$ & 0,0202 \\
\hline 6 & $\mathrm{H} 50$ & 0,0039 & G46 & 0,0027 & $\mathrm{C} 24$ & 0,0195 \\
\hline 7 & H49 & 0,0038 & C31-C32 & 0,0027 & $\mathrm{C} 27$ & 0,0189 \\
\hline 8 & $\mathrm{C} 16$ & 0,0025 & $\mathrm{C} 20$ & 0,0024 & $\mathrm{C} 26$ & 0,0188 \\
\hline 9 & J62-J63 & 0,0025 & $\mathrm{C} 29$ & 0,0024 & C16 & 0,0181 \\
\hline 10 & $\mathrm{C} 29$ & 0,0025 & D35 & 0,0024 & $\mathrm{C} 25$ & 0,0177 \\
\hline 11 & R_S & 0,0024 & G45 & 0,0023 & $\mathrm{C} 17$ & 0,0176 \\
\hline 12 & K66 & 0,0024 & $\mathrm{C} 28$ & 0,0023 & $\mathrm{C} 23$ & 0,0175 \\
\hline 13 & $\mathrm{C} 18$ & 0,0023 & $\mathrm{C} 22$ & 0,0023 & $\mathrm{C} 20$ & 0,0172 \\
\hline 14 & $\mathrm{C} 26$ & 0,0023 & $\mathrm{C} 27$ & 0,0022 & $\mathrm{C} 22$ & 0,0168 \\
\hline 15 & C31-C32 & 0,0023 & C30 & 0,0021 & $\mathrm{C} 10-\mathrm{C} 12$ & 0,0158 \\
\hline 16 & $\mathrm{C} 27$ & 0,0023 & $\mathrm{C} 16$ & 0,0020 & C13-15 & 0,0157 \\
\hline 17 & M72 & 0,0023 & $\mathrm{C} 17$ & 0,0019 & $\mathrm{C} 28$ & 0,0155 \\
\hline 18 & $\mathrm{C} 28$ & 0,0020 & $\mathrm{C} 23$ & 0,0019 & H51 & 0,0153 \\
\hline 19 & $\mathrm{C} 22$ & 0,0020 & $\mathrm{~F}$ & 0,0018 & $\mathrm{C} 18$ & 0,0137 \\
\hline 20 & $\mathrm{C} 24$ & 0,0019 & $\mathrm{C} 26$ & 0,0018 & $\mathrm{~F}$ & 0,0137 \\
\hline 21 & $\mathrm{C} 20$ & 0,0019 & O84 & 0,0016 & H50 & 0,0135 \\
\hline 22 & $\mathrm{C} 25$ & 0,0018 & C13-15 & 0,0015 & $\mathrm{C} 30$ & 0,0130 \\
\hline 23 & G47 & 0,0018 & $\mathrm{C} 10-\mathrm{C} 12$ & 0,0015 & I & 0,0122 \\
\hline 24 & $\mathrm{C} 17$ & 0,0018 & C18 & 0,0015 & D35 & 0,0105 \\
\hline 25 & C13-15 & 0,0018 & H49 & 0,0014 & M72 & 0,0102 \\
\hline 26 & $\mathrm{C} 23$ & 0,0017 & A03 & 0,0013 & $\mathrm{Q}$ & 0,0099 \\
\hline 27 & G45 & 0,0017 & H51 & 0,0013 & G47 & 0,0095 \\
\hline 28 & C19 & 0,0017 & I & 0,0012 & $\mathrm{~B}$ & 0,0095 \\
\hline 29 & $\mathrm{~F}$ & 0,0016 & B & 0,0011 & G46 & 0,0087 \\
\hline 30 & $\mathrm{C} 30$ & 0,0015 & Q & 0,0009 & G45 & 0,0085 \\
\hline 31 & M74-M75 & 0,0015 & H52 & 0,0008 & O84 & 0,0079 \\
\hline 32 & $\mathrm{~N}$ & 0,0015 & E37-E39 & 0,0008 & K66 & 0,0074 \\
\hline 33 & Q & 0,0014 & K66 & 0,0008 & M74-M75 & 0,0069 \\
\hline 34 & K65 & 0,0013 & A01 & 0,0007 & E37-E39 & 0,0067 \\
\hline 35 & $\mathrm{C} 10-\mathrm{C} 12$ & 0,0012 & M74-M75 & 0,0007 & J61 & 0,0066 \\
\hline 36 & A03 & 0,0012 & R_S & 0,0007 & A01 & 0,0060 \\
\hline 37 & I & 0,0012 & M72 & 0,0006 & $\mathrm{~N}$ & 0,0059 \\
\hline 38 & B & 0,0012 & J61 & 0,0006 & J62-J63 & 0,0058 \\
\hline 39 & P85 & 0,0011 & $\mathrm{~N}$ & 0,0006 & R_S & 0,0051 \\
\hline 40 & D35 & 0,0009 & E36 & 0,0006 & A03 & 0,0050 \\
\hline 41 & $\mathrm{~A} 02$ & 0,0008 & J62-J63 & 0,0005 & K65 & 0,0045 \\
\hline 42 & E37-E39 & 0,0008 & K65 & 0,0005 & $\mathrm{~A} 02$ & 0,0038 \\
\hline 43 & K64 & 0,0006 & L68 & 0,0004 & P85 & 0,0038 \\
\hline 44 & A01 & 0,0005 & K64 & 0,0004 & L68 & 0,0035 \\
\hline
\end{tabular}

\footnotetext{
${ }^{4}$ It is the evaluation of total advanced $\mathrm{CO}_{2}$ connection coefficient on the basis of the related sector line
} 


\begin{tabular}{ccccccc}
\hline $\mathbf{4 5}$ & E36 & 0,0004 & P85 & 0,0004 & E36 & 0,0035 \\
\hline $\mathbf{4 6}$ & L68 & 0,0003 & A02 & 0,0004 & K64 & 0,0032 \\
\hline \multicolumn{7}{c}{ Resource: } \\
\hline
\end{tabular}

Resource: EU SCIENCE UP, 2019; WIOD, 2016; Corsatea and others were created by the author using 2019 data

As seen in Table 3,total forward $\mathrm{CO}_{2}$ linkage coefficient, when partially evaluated, like in total backward $\mathrm{CO}_{2}$ linkage coefficient, the biggest coefficient of air, water, and land transport belongs to their own sectors as accounting technique of the method requires. With regards to air transport sector, the second biggest coefficient belongs to public administration and defence; compulsory social security sector and the third biggest coefficient belongs to telecommunications sector. Regarding water transport sector, the second biggest coefficient belongs to retail trade, except motor vehicles and motorcycles sector, and the third biggest coefficient belongs to the manufacture of coke and refined petroleum products sector. In terms of land transport and transport via pipelines, the second biggest coefficient belongs to warehousing and support activities for transportation and the third biggest coefficient belongs to the manufacture of coke and refined petroleum products sector. The $\mathrm{CO}_{2}$ emission order created by the outputs they give to each other for the realization of air, land and water transportation is as follows: water transport is in sixth and land transport is in seventh place for air transportation; land transport is in twenty-fifth and air transport is in twenty-seventh place for water transportation; air transport is in eighteenth and water transport is in twenty-first place for land transportation. The amount of $\mathrm{CO}_{2}$ emission resulting from the input-output activities of the land, air and water transportation sectors in both table 2 and table 3 is less than the total $\mathrm{CO}_{2}$ emission average as a result of the input-output activities of all sectors.

Examining whether the transportation sector's inter-period production chain has changed structurally is important to determine the necessary measures to be taken by clearly demonstrating the connection effects of the sector. For this purpose, in our study, the production chains were calculated using the first published 2000 table data and the last published 2014 table data by WIOD, Shapiro-Wilk test was applied to determine the correct statistical technique for the obtained coefficients. necessary hypotheses:

H_0: The sample came from the normal distribution

H_1: The sample did not come from the normal distribution

When Shapiro-Wilk test was applied, it was determined that the variables did not conform to the normal distribution. Therefore, Spearman test was applied to compare the production chain coefficients of 2000 and $2014^{5}$ (Chenery and Watanabe, 1958, p.496). The results are shown in table 4.

Table 4: 2002 and 2014 Spearman Production Chain Coeffcient

\begin{tabular}{lll}
\hline Sector Codes & Correlation coefficient & p-value \\
\hline $\mathrm{A} 01 * * *$ & 0,739 & 0,0000 \\
\hline $\mathrm{A} 02^{* * *}$ & 0,778 & 0,0000 \\
\hline $\mathrm{A} 03 * * *$ & 0,725 & 0,0000 \\
\hline $\mathrm{B} * *$ & 0,639 & 0,0000 \\
\hline $\mathrm{C} 10-\mathrm{C} 12^{* *}$ & 0,687 & 0,0000 \\
\hline $\mathrm{C} 13-\mathrm{C} 15^{* *}$ & 0,653 & 0,0000 \\
\hline $\mathrm{C} 16^{* *}$ & 0,665 & 0,0000 \\
\hline $\mathrm{C} 17^{* *}$ & 0,614 & 0,0000 \\
\hline $\mathrm{C} 18^{* *}$ & 0,604 & 0,0000 \\
\hline $\mathrm{C} 19^{* *}$ & 0,646 & 0,0000 \\
\hline $\mathrm{C} 20^{* *}$ & 0,599 & 0,0000 \\
\hline $\mathrm{C} 22^{* *}$ & 0,649 & 0,0000 \\
\hline $\mathrm{C} 23 * *$ & 0,637 & 0,0000 \\
\hline
\end{tabular}

\footnotetext{
${ }^{5}$ SPSS 23 software was used in the calculation
} 


\begin{tabular}{lll}
\hline C24** & 0,635 & 0,0000 \\
\hline C25** & 0,627 & 0,0000 \\
\hline C26** & 0,649 & 0,0000 \\
\hline C27** & 0,643 & 0,0000 \\
\hline C28** & 0,686 & 0,0000 \\
\hline C29** & 0,67 & 0,0000 \\
\hline C30*** & 0,712 & 0,0000 \\
\hline C31_C32** & 0,699 & 0,0000 \\
\hline D35** & 0,61 & 0,0000 \\
\hline E36** & 0,618 & 0,0000 \\
\hline E37-E39** & 0,611 & 0,0000 \\
\hline F** & 0,685 & 0,0000 \\
\hline G45** & 0,673 & 0,0000 \\
\hline G46** & 0,608 & 0,0000 \\
\hline G47** & 0,56 & 0,0000 \\
\hline H49** & $\mathbf{0 , 6 2 4}$ & $\mathbf{0 , 0 0 0 0}$ \\
\hline H50** & $\mathbf{0 , 5 3}$ & $\mathbf{0 , 0 0 0 0}$ \\
\hline H51** & $\mathbf{0 , 5 7 6}$ & $\mathbf{0 , 0 0 0 0}$ \\
\hline H52** & 0,532 & 0,0000 \\
\hline I** & 0,681 & 0,0000 \\
\hline J61** & 0,491 & 0,0000 \\
\hline J62_J63** & 0,41 & 0,0010 \\
\hline K64** & 0,473 & 0,0000 \\
\hline K65** & 0,527 & 0,0000 \\
\hline K66** & 0,527 & 0,0000 \\
\hline L68*** & 0,701 & 0,0000 \\
\hline M72** & 0,444 & 0,0000 \\
\hline M74_M75** & 0,667 & 0,0000 \\
\hline$N^{* *}$ & 0,451 & 0,0000 \\
\hline O84** & 0,605 & 0,0000 \\
\hline P85** & 0,508 & 0,0000 \\
\hline Q* & 0,356 & 0,0050 \\
\hline R_S** & 0,577 & 0,0000 \\
\hline & $*$ Weak relationship in the same direction, **Middle relationship in the same direction, $* * *$ Strong relationship in the same \\
direction & & \\
& Resource: EU SCIENCE UP $2019 ;$ WIOD, 2016; Corsatea and others & \\
\hline & & were created by the author using 2019 data
\end{tabular}

As seen in Table 4, the transportation sector proves that the vast majority of other sectors do not show a significant structural change in inter-period production by showing a moderately identical relationship as seen in the Spearman correlation coefficient. Therefore, there is no significant structural change in the sectors of the transport sector causing $\mathrm{CO}_{2}$ emissions. Inputoutput analysis is naturally suitable for future projections as it is based on the basic assumption that the ratios such as input, capital, technology import are fixed. In this context, the similarity of the transportation sector with the previous periods (TÜIK, 2020) will be a guide for the policy measures to be taken for $\mathrm{CO}_{2}$ emission reduction since the production chain will display similar features in the future.

According to the literature review and WIOD Turkey data analysis, to prevent the climate change and to avoid environmental negative externalities, emission values produced based on the relationships of transport sectors in Turkey with other sectors need reducing. With this objective, in the content of the study developments of policy recommendations about emission reduction which will be made with the support of political documents, strategy and action plan of Turkey in transportation are included.

\section{Developing Policy Recommendations for Turkey's Transport Sector}

Day by day, greenhouse gas emissions on particularly sectoral basis contribute significantly to tangled climate change on a global scale. In most of the developed and 
developing countries, the impact of $\mathrm{CO}_{2}$ emission that is produced based on economical activities and is an important greenhouse gas on climate change is an important issue which should be thought over sensitively. In Turkey, a total proportion of a single unit $\mathrm{CO}_{2}$ emission that aviation, maritime, road and pipeline transport sectors generate the environment come the fourth in all sectors. Transport sector, which has been seriously accelerating in besides the intercity and inner-city passenger transport and in freight recently and where $\mathrm{CO}_{2}$ emissions are released more into the environment resulting from fossil fuel usage, consumes natural environment and built environment more because of this impact.

As well as a number of policies implemented to reduce transportation-induced emissions causing global warming and to protect environmental values in Turkey, proposals are put forward in policy documents and action plans created by the efforts of various institutions for the prevention of potential adverse effects of transportation sector in near future. Since 2000s, it is seen that policy documents have been prepared to reduce the environmental impacts of the transportation sector in the vision, goals, objectives and strategies included in both development plans, programs and in different policy and strategy documents. These studies include proposals to be able to observe the impact on climate change directly on local scale in Turkey and indirectly on global scale.

In most policy documents, the concepts of sustainability, efficiency, energy efficiency, livability, environmental awareness and human orientation are considered as key vision keys. Recently, industry 4.0, smart cities, smart environment, smart transportation, smart society, internet of things, remote sensing, sensors in communication with each other, artificial intelligence, electronic control systems, environmentally friendly modes of transport, interspecies integration, promoting low emission motorless transportation are all quite popular; and new developments are inevitable in this field in Turkey as a necessity of development of new technology era.

With the Covid-19 pandemic which affected the world, concerns about social distancing came to the fore especially in the transportation sector. After taking measures by reducing total passenger carrying capacity in half and imposing restrictions for bus and plane travels in intercity and international transportation in Turkey in pandemic period, when the restrictions are removed, people will increase their private automobile travel, the number of trips by public transport will also increase and more $\mathrm{CO}_{2}$ emissions will be produced. Therefore, considering the analysis results obtained in the current situation, various policies and measures should be presented for post Covid-19 measures:

- Due to the low emission production, making rail system widespread in urban transportation by taking into account the settlement structure and urban densities where the topographic structure of the city is appropriate (Akdemir and Önder, 2019).

- $\quad$ Making alternative modes of transportation such as park\&ride, street tram, Bus Rapid Transit, carsharing, bike sharing, carpooling take place among the priority public transportation investments in cities with appropriate topographic and economical structure (Kaplan and Önder, 2017),

- $\quad$ Ensuring that priority is given to disadvantaged groups in public transportation by prioritizing the transportation of women, children, the elderly and the disabled (Öktem, Önder, Ulvi and Uysal, 2019; Önder, 2020).

- $\quad$ Ensuring that the existing transportation infrastructure is used in an energyefficient, cost-effective, human-oriented and environmentally friendly manner (T.C. Enerji ve Tabi Kaynaklar Bakanlığı, 2017), 
- $\quad$ Preventing time and financial losses and extra emission production with the integration of land-air-water transportation types at various stations, ports and airports (T.C. Cumhurbaşkanlığı Strateji ve Bütçe Başkanlığı, 2019),

- $\quad$ Building an efficient self-supervising transportation system in communication with each other by supporting the efficient use of intelligent transportation systems and applications in land-air-water transportation (Akdemir and Önder, 2020, pp.239-242),

- $\quad$ Enabling widespread use of electric, hybrid, solar, hydrogen, wind powered vehicle types that will encourage the use of energy produced through renewable energy sources in freight shipment and passenger transportation, (T.C. Çevre ve Şehircilik Bakanlığı, 2019a; T.C. Ulaştırma Denizcilik ve Haberleşme Bakanlığı, 2014; Önder and Ulukavak, 2019, pp.103104)

- $\quad$ Encouraging the preference of multimodal modes of transportation in which suitable price tariffs are arranged in freight shipment and passenger transportation, (T.C. Enerji ve Tabi Kaynaklar Bakanlığı, 2012; T.C. Kalkınma Bakanlığı, 2013),

- $\quad$ Shifting the freight transport rate of road transportion to alternative transportion types with relatively low emissions, (T.C. Çevre ve Şehircilik Bakanlığı, 2011; T.C. Ulaştırma Denizcilik ve Haberleşme Bakanlığı, 2011),

- $\quad$ Commissioning of environmentally friendly vehicles by encouraging the use of new generation technologies in railway transportation, (T.C. Çevre ve Şehircilik Bakanlığı, 2010),

- $\quad$ Providing less fuel consumption by preferring the transportation of products of vital importance light in weight but heavy in value in air transportation, prioritizing the airway which is a fast mode in passenger transportation, (T.C. Ulaştırma Denizcilik ve Haberleşme Bakanlığı, 2011; T.C. Çevre ve Şehircilik Bakanlığı, 2010),

- $\quad$ Encouraging the transportation of larger-scale cargoes to longer distances by improving water transportation especially in the field of freight transportation, (T.C. Enerji ve Tabi Kaynaklar Bakanlığı, 2017; T.C. Cumhurbaşkanlığı Strateji ve Bütçe Başkanlığ1, 2019),

- $\quad$ Encouraging less energy consumption and less emission production by ensuring interspecies integration in urban public transport, (T.C. Çevre ve Şehircilik Bakanlığ $1,2019 b$ ),

- Gradually reducing the types of transportation that cause high fuel consumption and environmental pollution and limit the use of fossil fuels with high taxation, (T.C. Enerji ve Tabi Kaynaklar Bakanlı̆̆g1, 2012),

- $\quad$ Ensuring that non-motorized transportation types such as pedestrian and bicycle are preferred more in urban transportation (KENTGES, 2010),

- $\quad$ Supporting policies such as congestion charging, road toll, area charging, road tax should be implemented to reduce congestion and to limit emission production in areas with high emission density in the city.

\section{Result and Discussion}

Today, it is aimed to reduce air pollution in many countries. Air pollution is expected to decrease when it comes to stopping production, decreasing energy consumption, not using transportation means, stopping eating, drinking, shopping, and entertainment activities. For example, a decrease in air pollution has been observed after people put themselves in quarantines in their homes, out-of-home activities and transportation activities are restricted and many factories have stopped production due to the Covid-19 pandemic which has been 
spreading all over the world from China today and triggering the supply shock. Satellite images published by NASA clearly shows a reduction in air pollution compared to January 1-20, 2020 and February 10-25, and compared to last year's satellite images (NASA, 2020). There is an expectation of financial shock and recession as a result of struggling to get rid of the trade war on the one hand and to fight the COVID-19 virus on the other hand (World Bank, 2020, pp.23 ). The important thing is to reduce air pollution in periods when there is no economic recession and when production continues, the products are delivered to people, and people actively use the means of transportation.

The economic workspace of input-output analysis is mainly the sectors. Today, all sectors are interconnected. Sectors are the production elements that turn the inputs into output with the production techniques they apply. However, every production element brings about negative environmental externality. In this study, $\mathrm{CO}_{2}$ emission was dealt with as negative environmental externality and environmental input-output analysis was applied to all sectors in Turkey and measures, policies and recommendations were evaluated specific to the transportation sector.

In the WIOD input-output table, the transportation sector consists of three sectors as land transportation, air transportation and water transportation. $\mathrm{CO}_{2}$ equivalent of one dollar production is $0,1356 \mathrm{kt}$ in land transportation, $0,3437 \mathrm{kt}$ in air transportation, $0,1068 \mathrm{kt}$ in water transportation. $\mathrm{BL}_{\mathrm{j}}$ coefficients are $0,4500 \mathrm{kt} \mathrm{CO}_{2}$ equivalent in land transportation, $0,8929 \mathrm{kt}$ $\mathrm{CO}_{2}$ equivalent in air transportation, $0,3619 \mathrm{kt} \mathrm{CO}_{2}$ equivalent in water transportation respectively. $\mathrm{FL}_{\mathrm{i}}$ coefficients are $1,1895 \mathrm{kt} \mathrm{CO}_{2}$ equivalent in land transportation, $0,7840 \mathrm{kt}$ $\mathrm{CO}_{2}$ equivalent in air transportation and $0,3234 \mathrm{kt} \mathrm{CO}_{2}$ equivalent in water transportation.

Determining whether the transportation sectors' inter-period production chain has changed structurally is important to determine the policy measures to be taken for $\mathrm{CO}_{2}$ emission reduction. In this context, it was concluded that the input components used in production did not differ significantly with the calculated Spearman Correlation. When these analysis results are evaluated together; We suggest measures to determine a policy for establishing humanoriented transportation system in which the existing transportation infrastructure is planned to be energy and cost effective, environmentally friendly vehicle types are popularized, nonmotorized transportation types are preferred, transportation is intensified among different transportation sectors generating emission, there is less fuel consumption in air transportation, inter-species integration is provided and alternative transportation systems are preferred in urban public transportation, fuel consumption is reduced and fossil fuel use is restricted, the policies are applied to limit the emission intensity and emission production of the city and renewable and sustainable environmentally friendly fuel types are preferred.

In the input-output tables published in the WIOD database, the production and use of environmentally friendly fuel types and environmentally friendly vehicles such as electric, hybrid, solar, hydrogen, wind powered vehicles are not included in the sector. It is suggested by us that these sectors will be included in the input-output tables to be created after that. In such a case, to reduce the $\mathrm{CO}_{2}$ emissions of the sectors, expanded environmental input-output analyzes can be carried out by preparing various scenarios where the coefficients of coal and petroleum derivatives are reduced in percentage and the environmentally friendly fuel types are increased in percentage in input-output tables; the coefficients of use of the vehicles currently being used are reduced in percentage and the coefficients of environmentally sensitive vehicles are increased in percentage. Therefore, we foresee that the validity of the measures and policies put forward within the scope of this study will be proved. 


\section{References}

Afonso, A. V., Arto, I., Corsatea, T. D., Lindner, S., Neuwahl, F., Roman, M. V., \& RuedaCantuche, J. M. (2019). World input-output database environmental accounts. (No. JRC116234). Joint Research Centre (Seville site).

Akbostanc1, E., Tunç, İ. \& Türüt, S. (2006). $\mathrm{CO}_{2}$ emissions vs. $\mathrm{CO}_{2}$ responsibility: an inputoutput approach for the Turkish economy. ERC Working Papers in Economics 06/04, Ankara: METU.

Akdemir, F. \& Önder, H. G. (2019). Türkiye'deki kentiçi raylı toplu taşıma sistemlerinin ulaşım ana planları bağlamında değerlendirilmesi. Demiryolu Mühendisliği , 10, 23-37.

Akdemir, F. \& Önder, H., G. (2020). Endüstri 4.0'ın etkisindeki ak1llı kentin arazi kullanım ve ulaşım paradigmaları. Çiğdem, S. \& Boztaş A. (Ed.) Endüstri 4.0'dan toplum 5.0'a güncel yaklaşımlar. (233-253). Ankara: Nobel Yayınevi.

Alcántara, V. \& Padilla, E. (2006). An input-output analysis of the "key" sectors in $\mathrm{CO}_{2}$ emissions from a production perspective: an application to the Spanish economy. Departament d'Economia Aplicada, Universitat Autonoma de Barcelona, Issue Barcelona. Spain

Alcántara, V. \& Padilla, E. (2009). Input-output subsystems and pollution: An application to the service sector and $\mathrm{CO}_{2}$ emissions in Spain. Ecological Economics, 68(3), 905-914.

Altınışık, İ. \& Peker, H. S. (2011). Negatif dışsallıkların içselleştirilmesi açısından karbon ticareti. Gümüşhane Üniversitesi Sosyal Bilimler Enstitüsü Elektronik Dergisi, 2(4).

Andrei, J., Cristina, M., Mieila, M., Nica, E. \& Popescu, G. H., (2016). The impact and determinants of environmental taxation on economic growth communities in Romania. Energies, 9(11), 902.

Andreoni, V., Arto, O. I., Genty, A., Rueda-Cantuche, J., \& Villanueva, K. A. (2012). Global resources use and pollution: vol. I, production, consumption and trade (1995-2008). Luxembourg: European Commission Joint Research. EUR 25462.

Arto, I., Genty, A. \& Neuwahl, F. (2012). Final database of environmental satellite accounts: Technical report on their compilation. WIOD Deliverable, 4(6).

Arto, I., Peters, G. P. \& Rueda-Cantuche, J. M. (2014). Comparing the GTAP-MRIO and WIOD databases for carbon footprint analysis. Economic Systems Research, 26(3), 327353.

Baker, S. (2006). Sustainable development. New York: Routledge Taylor and Francis Group.

Baumert, N., Jiborn, M., Kander, A., Kulionis, V. \& Nielsen, T. (2019). Global outsourcing of carbon emissions 1995-2009: A reassessment. Environmental Science \& Policy, 92, 228-236.

Bednar-Friedl, B., Muñoz, P., Nabernegg, S., Titz, M. \& Vogel, J. (2019). National policies for global emission reductions: effectiveness of carbon emission reductions in international supply chains. Ecological Economics, 158, 146-157.

Benli, Y. \& Peker, S.C (2018). Elektirik tüketimi, $\mathrm{CO}_{2}$ emisyonu ve kişi başı gayrisafi yurtiçi hasıla arasındaki ilişkinin incelenmesi. Yalçın, A. (Ed.) Amprik bir çalışma. Bilimsel Araştırmalar Kitabı, İktisadi ve İdari Bilimler (287-294). Ankara: Akademisyen Kitabevi. 
Bennett, J. (2019). Book review: biodiversity and ecological economics: participation, values and resource management. Pacific Economic Bulletin, 16(1), 1-12.

Blair, D. P. \& Miller, R. E. (2009). Input-output analysis: foundations and extensions. New York: Cambridge University Press.

Bocutoğlu, E. (2016). İktisadi düşünceler tarihi. (3. Bask1). Ankara: Ekin Yayınevi.

Boland, J., Buckley, J. D., Piantadosi, J., Reynolds, C. J. \& Weinstein, P. (2015). Evaluation of the environmental impact of weekly food consumption in different socio-economic households in Australia using environmentally extended input-output analysis. Ecological Economics, 111, 58-64.

Brouwer, R., Eamen, L. \& Razavi, S. (2020). The economic impacts of water supply restrictions due to climate and policy change: a transboundary river basin supply-side input-output analysis. Ecological Economics, 106532.

Cadarso, M. Á., Gómez, N., López, L. A. \& Tobarra, M. Á. (2010). CO emissions of international freight transport and offshoring: Measurement and allocation. Ecological Economics, 69(8), 1682-1694.

Cahen-Fourot, L., Campiglio, E., Dawkins, E., Godin, A. \& Kemp-Benedict, E. (2020). Looking for the inverted pyramid: An application using input-output networks. Ecological Economics, 169, 106554.

Cansino, J. M., Rodríguez-Arévalo, M. L. \& Sánchez-Braza, A. (2015). Driving forces of Spain' s $\mathrm{CO}_{2}$ emissions: a LMDI decomposition approach. Renewable and Sustainable Energy Reviews, 48, 749-759.

Cella, G. (1984). The input-output measurement of interindustry linkages. Oxford Bulletin of Economics and Statistics, 46(1), 73-84.

Chatellier, D.L. \& Sheinbaum-Pardo, C. (2017). Assessing the impacts of final demand on $\mathrm{CO}_{2-}$ eq emissions in the Mexican Economy: An input-output Analysis. Energy and Power Engineering, 9(1), 40-54.

Chen, L., Huang, G. \& Sun, C. (2020). Decomposition analysis of $\mathrm{CO}_{2}$ emissions embodied in the international trade of Russia. Sustainability, 12(1), 323.

Chenery, H. \& Watanabe, B. (1958). Tsunehiko; "International comparison of the structure of production". Econometrica, 26(4), 487-521.

Chung, W., Yeung, I. M. \& Zhou, G. (2013). A study of energy efficiency of transport sector in China from 2003 to 2009. Applied Energy, 112, 1066-1077.

Çağatay, S. \& Özeş, R. (2013). Ulaştırma sektörü ve hanehalkı enerji tüketiminde alternatif enerji kullanımının çevresel ve ekonomik etkileri. Nevşehir Hacı Bektaş Veli Üniversitesi Sosyal Bilimler Enstitüsü Dergisi, 3, 158-180.

Dağdemir, Ö. (2003). Çevre sorunlarına ekonomik yaklaşımlar ve optimal politika arayışları. Ankara: Gazi Kitabevi.

De Vries, G. J., Dietzenbacher, E., Los, B., Stehrer, R. \& Timmer, M. P. (2015). An illustrated user guide to the world input-output database: the case of global automotive production. Review of International Economics, 23(3), 575-605.

Dietzenbacher, E. \& Los, B. (2000). Structural decomposition analyses with dependent determinants. Economic System Research, 12(4), 497-514. 
Du, H., Lee, L.C., Li, J., Wang, M. \& Wang, Y. (2019). A review of input-output model application hot spots in the energy and environment fields based on co-words network analysis. Environmental Reviews, 27(4), 567-574.

EU SCIENCE HUB (2019). WIOD Environmental Accounts (2019). Retrieved 5 January 2020 from: https://ec.europa.eu/jrc/en/research-topic/economic-environmental-and-socialeffects-of-globalisation.

Faber, M., Proops, J. \& Wagenhals, G. (2012). Reducing $\mathrm{CO}_{2}$ emissions: a comparative inputoutput-study for Germany and the UK. Berlin: Springer Science \& Business Media.

Fan, X. \& Liu, H. (2017). Value-added-based accounting of $\mathrm{CO}_{2}$ emissions: a multi-regional input-output approach. Sustainability, 9(12), 2220.

Güler, İ. (2019). İktisadi kalkınma temelinde gayrimenkul ekonomisi. (1. Bask1). Ankara: Gazi Kitabevi.

Güler, İ. (2020). Post-pandemi süreci için ekonomik kalkınma arayışı: Türkiye örneği. Adam Akademi Sosyal Bilimler Dergisi, 10(1), 19-50.

Güler, İ. \& Küçükkiremitçi, O. (2020). Ticaret savaşlarl ekseninde türkiye'de üretimin ithalata bağımlılık düzeyinin dönemler arası benzerlik analizi. Çetinkaya, M. \& Muratoğlu, G. (Ed.) In: Ticaret ve kur savaşlart-küresel ekonomik politiğe yansimaları küresel ekonomik politiğe yansımaları (119-156). (1. Bask1).Ankara: Gazi Kitabevi

Hadjikakou, M. (2016). Trimming the excess: environmental impacts of discretionary food consumption in Australia. Australia: Ecological Economics, 131(2017), 119-128.

Hazari, B. R. (1970). Empirical identification of key sectors in the Indian economy. The Review of Economics and Statistics, 52(3), 301-305.

Hertwich, E. G., Ivanova, D., Lundström, J. R., Quist, J., Stadler, K., Vita, G. \& Wood, R. (2019). The environmental impact of green consumption and sufficiency lifestyles scenarios in europe: Connecting local sustainability visions to global consequences. Ecological Economics, 164, 106322.

Hickel, J. (2020). The sustainable development index: measuring the ecological efficiency of human development in the anthropocene. Ecological Economics, 167, 106331.

Hirschman, A. O. (1978). The strategy of economic development. New Haven: Yale University Press.

Hotelling, H. (1931). The economics of exhaustible resources. Journal of Political Economy, $39,2$.

IEA-International Energy Agency, (2020). Türkiye'de 1990-2018 yılları arasinda $\mathrm{CO}_{2}$ üretiminin sektörel dağılımı, Türkiye raporu. Retrieved 2 March 2020 from: https://www.iea.org/data-and-

statistics?country $=$ TURKEY \& fuel $=\mathrm{CO}_{2} \% 20$ emissions \&indicator $=\mathrm{CO}_{2} \% 20$ emissions $\% 20$ by $\% 20$ sector.

Kaplan, H. \& Önder, H. G. (2017). Ankara'da park et-devam et sisteminin modellenmesi ile yolculuk değişimine bağlı emisyon azaltımının ölçülmesi. Gazi Üniversitesi Fen Bilimleri Dergisi Part C: Tasarım ve Teknoloji, 5(1), 139-152.

KENTGES. (2010). Bütünleşik Kentsel Gelişme Stratejisi ve Eylem Planı 2010-2023. Ankara. 
Korum, U. (1963). Input-output analizi. (Yayın No. 164-146). Ankara: Ankara Üniversitesi Siyasal Bilgiler Fakültesi Yayınları.

Kuznets, S. (1955). Economic growth and income 1nequality. American Economic Review, 45(1), 1-28.

Küçükkiremitçi, O. (2011). Türkiye sanayi strateji belgesi temelinde imalat sanayinin yapısal analizi. Memleket Siyaset Yönetim Dergisi, 15, 53-94.

Küçükkiremitçi, O. (2013). Türkiye ve Avrupa Birliği Üyesi ülkelerin üretim yapılarının girdiçıktı analizi ve benzeşme testleri yöntemiyle karşılaştırılması. Doktora Tezi, Gazi Üniversitesi Sosyal Bilimler Enstitüsü, Ankara.

Leontief, W. (1936). Quantitative input and output relations in the economic systems of the United States. The Review of Economic Statistics, 105-125.

Leontief, W. (1946). Exports, imports, domestic output, and employment. The Quarterly Journal of Economics, 171-193.

Leontief, W. (1949). Structural matrices of national economies. Econometrica: Journal of the Econometric Society, 273-282.

Leontief, W. (1953a). Domestic production and foreign trade: the American capital position reexamined. Proceedings of the American Philosophical Society, 97(4), 332-349.

Leontief, W. (1953b). Studies in the structure of the American economy (pp. 116-181). New York: Oxford University Press.

Leontief, W. (1970). Environmental repercussions and the economic structure: An input-output approach. The Review of Economics and Statistics, 262-271.

Leontief, W. (1986). Input-output economics. Oxford University Press on Demand.

Litman, T. (2016). Well measured developing indicators for sustainable and livable transport planning. Victoria Transport Policy Institute.

Liu, Y., Wang, S., Zhang, Y., Zhang, Z. \& Zhao, Y. (2015). Linkage analysis of sectoral $\mathrm{CO}_{2}$ emissions based on the hypothetical extraction method in South Africa. Journal of Cleaner Production, 103, 916-924.

Mach, R., Ščasný, M. \& Weinzettel, J. (2018). Environmental Impact of consumption by Czech households: hybrid input-output analysis linked to household consumption data. Ecological Economics, 149, 62-73.

Machado, G., Schaeffer, R. \& Worrell, E. (2001). Energy and carbon embodied in the international trade of Brazil: an input-output approach. USA: Ecological Economics, 39, 409-424.

Mankiw, G. (1997). Principles of microeconomics. The Dryden Press, Harvard University: United States of America.

NASA (2020). How the coronavirus is (and is not) affecting the environment. Retrieved 31 March 2020

from: https://earthobservatory.nasa.gov/blogs/earthmatters/2020/03/05/how-the-coronavirusis-and-is-not-affecting-the-environment/.

Newton, P., Prasad, D., Sproul, A. \& White, S. (2019). Decorbonising the built environment charting the transation. Australia: Palgrave Macmillan. 
Öktem, M. K., Önder, H. G., Ulvi, H. \& Uysal, M. (2019). The comparative analysis of urban transport in ankara by gender and age groups. Megaron Journal, 14(4).

Önder, H. G. \& Ulukavak, U. (2019). Akıllı kent. Sezer, Ö. \& Kayan, A. (Ed.) Kent tartışmaları ve yeni yaklaşımlar (89-116). Ankara: Orion Kitabevi.

Önder, H. G. (2017). Principles and goals of sustainable transportation. Benaabidate, L., Koleva I., \& Yüksel, Ü. D. (Ed.) Ecology, planning and design (Chapter 21: 218-225). Sofia: St. Kliment Ohridski University Press.

Önder, H. G. (2020). Kadın duyarlı ulaşım önceliklerinin belirlenmesi ve politika üretimi: Ankara örneği. OPUS Uluslararası Toplum Araştırmaları Dergisi, 15(23), 1-1.

Peker, H. S. (2015). Energy supply security of turkey and measuring: An application on Turkey's energy supply security. Çankırı Karatekin University Journal of the Faculty of Economcs et Admimistrative Sciences, 5(2), 763.

Quesnay, F. (1758). Tableau economique. Kuczynski, M. \& Meek, R. L. (Eds.)., In: Quesnay's Tableau Economique. Macmillan, London.

Rasmussen, P.N. (1956). Studies in intersectorel relations. Amsterdam: Nourth-Holland.

Renner, S. (2017). Poverty and distributional effects of a carbon tax in Mexico. (No. 223). Courant Research Centre: Poverty, Equity and Growth-Discussion Papers.

Schmidt, S., Tukker, A. \& Wood, R. (2020). Towards accepted procedures for calculating international consumption-based carbon accounts. Climate Policy, 1-17.

Schultz, S. (1977). Approaches to identifying key sectors empirically by means of input-output analysis. The Journal of Development Studies, 14(1), 77-96.

Soleymani, S. (2019). $\mathrm{CO}_{2}$ emissions patterns in 7 top carbon emitter economies: The case of transport sector. Energy, 168, 989-1001.

T.C. Cumhurbaşkanlığı Strateji ve Bütçe Başkanlığı. (2019). On Birinci Kalkınma Planı 20192023. Ankara.

T.C. Çevre ve Şehircilik Bakanlığı. (2010). Ulusal İklim Değişikliği Stratejisi 2010-2023. Ankara.

T.C. Çevre ve Şehircilik Bakanlığı. (2011). İklim Değişikliği Eylem Planı 2011-2023. Ankara.

T.C. Çevre ve Şehircilik Bakanlığı. (2019a). Ulusal Akıllı Şehirler Stratejisi ve Eylem Planı. Ankara.

T.C. Çevre ve Şehircilik Bakanlığg. (2019b). Akıllı Şehirler Beyaz Bülten. Ankara.

T.C. Enerji ve Tabi Kaynaklar Bakanlığı. (2012). Enerji Verimliliği Strateji Belgesi, 20122023. Ankara.

T.C. Enerji ve Tabi Kaynaklar Bakanlığı. (2017). Ulusal Enerji Verimliliği Eylem Planı 20172023. Ankara.

T.C. Kalkınma Bakanlığı. (2013). Bölgesel Gelişme Ulusal Stratejisi 2014-2023. Ankara.

T.C. Ulaştırma Denizcilik ve Haberleşme Bakanlığı. (2011). Hedef 2023 Türkiye Ulaşım ve Iletişim Stratejisi 2011. Ankara.

T.C. Ulaştırma Denizcilik ve Haberleşme Bakanlığı. (2014). Akıllı Ulaşım Sistemleri Strateji Belgesi 2014-2023 ve Eki Eylem Planı 2014-2016. Ankara. 
Taşdoğan, B. \& Taşdoğan, C. (2014). Türkiye'deki üretken sektörlerin göreli önemi ve emisyon sorumluluğu: 2002-2011 emissions responsibility and relative importance of the productive sectors in Turkey: 2002-2011. (Bildiri No:1095).Üsküp: Avrasya Ekonomileri Uluslararası Konferansı Online Bildiri Kitabı.

Tokito, S. (2018). Environmentally-targeted sectors and linkages in the global supply-chain complexity of transport equipment. Ecological Economics, 150, 177-183.

Türkiye İstatistik Kurumu, (2020). Girdi-çıktı tabloları, metaveri, analitik çerçeve, kapsam, tanimlar ve siniflamalar, Retrieved 1 February 2020 from: http://www.tuik.gov.tr/PreTablo.do?alt_id=1021.

Ulucak, R. (2018). İktisatta çevreci dönüşüm: Ekolojik makro iktisat. Erciyes Üniversitesi İktisadi ve İdari Bilimler Fakültesi Dergisi, (51), 127-149.

UNFCCC-Under the United Nations Framework Convention on Climate Change, (2019). UNFCCC fourth biennial report of Turkey, prepared by United Nations Development Programme Country Office Turkey, Ankara.

Van Den Bergh, J. C. (2001). Ecological economics: themes, approaches, and differences with environmental economics. Regional Environmental Change, 2(1), 13-23.

Van Dender, K. (2009). Energy policy in transport and transport policy. Energy Policy, 37(10), 3854-3862.

Walras, L. (1954). Elements of pure economics, or the theory of social wealth. (W. Jaffé, Çev.). (Originate 1874). Homewood: Ill.: R.D. Irwin.

World Bank (2020). East Asia and pacific in the time of COVID-19. Washington: World Bank East Asia and Pacific Economic Update April 2020.

World Input-Output Database, (2016). National input-output tables. Retrieved 5 February 2020 from: http://www.wiod.org/database/niots16.

\section{Appendix}

\begin{tabular}{ll}
\hline CODE & SECTOR \\
\hline A01 & Crop and animal production, hunting and related service activities \\
\hline A02 & Forestry and logging \\
\hline A03 & Fishing and aquaculture \\
\hline B & Mining and quarrying \\
\hline C10-C12 & Manufacture of food products, beverages and tobacco products \\
\hline C13-C15 & Manufacture of textiles, wearing apparel and leather products \\
\hline C17 & Manufacture of wood and of products of wood and cork, except furniture; manufacture of articles of \\
& straw and plaiting materials \\
\hline C18 & Manufacture of paper and paper products \\
\hline C19 & Printing and reproduction of recorded media \\
\hline C20 & Manufacture of coke and refined petroleum products \\
\hline C22 & Manufacture of chemicals and chemical products \\
\hline C23 & Manufacture of rubber and plastic products \\
\hline C24 & Manufacture of basic metals \\
\hline C25 & Manufacture of fabricated metal products, except machinery and equipment \\
\hline C26 & Manufacture of computer, electronic and optical products \\
\hline C27 & Manufacture of electrical equipment \\
\hline C28 & Manufacture of machinery and equipment n.e.c. \\
\hline C29 & Manufacture of motor vehicles, trailers and semi-trailers \\
\hline C30 & Manufacture of other transport equipment \\
\hline C31-C32 & Manufacture of furniture; other manufacturing \\
\hline D35 & Electricity, gas, steam and air conditioning supply \\
\hline & \\
\hline
\end{tabular}




\begin{tabular}{ll}
\hline E36 & Water collection, treatment and supply \\
\hline E37-E39 & $\begin{array}{l}\text { Sewerage; waste collection, treatment and disposal activities; materials recovery; remediation activities } \\
\text { and other waste management services }\end{array}$ \\
\hline F & Construction \\
\hline G45 & Wholesale and retail trade and repair of motor vehicles and motorcycles \\
\hline G46 & Wholesale trade, except of motor vehicles and motorcycles \\
\hline G47 & Retail trade, except of motor vehicles and motorcycles \\
\hline H49 & Land transport and transport via pipelines \\
\hline H50 & Water transport \\
\hline H51 & Air transport \\
\hline I & Warehousing and support activities for transportation \\
\hline J61 & Accommodation and food service activities \\
\hline J62-J63 & Telecommunications \\
\hline K64 & Computer programming, consultancy and related activities; information service activities \\
\hline K65 & Financial service activities, except insurance and pension funding \\
\hline K66 & Insurance, reinsurance and pension funding, except compulsory social security \\
\hline L68 & Activities auxiliary to financial services and insurance activities \\
\hline M72 & Real estate activities \\
\hline M74-M75 & Scientific research and development \\
\hline Other professional, scientific and technical activities; veterinary activities \\
\hline O84 & Administrative and support service activities \\
\hline P85 & Public administration and defence; compulsory social security \\
\hline Q & Education \\
\hline & Human health and social work activities \\
\hline & Other service activities \\
\hline
\end{tabular}

